\title{
Resistant Starch-Based Edible Coating Composites for Spray-Dried Microencapsulation of Lactobacillus acidophilus, Comparative Assessment of Thermal Protection, In Vitro Digestion and Physicochemical Characteristics
}

\author{
Zafarullah Muhammad ${ }^{1}$, Rabia Ramzan ${ }^{2}$, Ruifen Zhang ${ }^{1}$ and Mingwei Zhang ${ }^{1, *}$ \\ 1 Sericultural \& Agri-Food Research Institute Guangdong Academy of Agricultural Sciences Key Laboratory of \\ Functional Foods, Ministry of Agriculture and Rural Affairs/Guangdong Key Laboratory of Agricultural \\ Products Processing, Guangzhou 510610, China; zafmuhammad@mail.hzau.edu.cn (Z.M.); \\ ruifenzhang@163.com (R.Z.) \\ 2 College of Food Science and Technology, Huazhong Agricultural University, Wuhan 430070, China; \\ rabiaramzan@webmail.hzau.edu.cn \\ * Correspondence: mwzhh@vip.tom.com
}

Citation: Muhammad, Z.; Ramzan, R.; Zhang, R.; Zhang, M. Resistant Starch-Based Edible Coating Composites for Spray-Dried Microencapsulation of Lactobacillus acidophilus, Comparative Assessment of Thermal Protection, In Vitro Digestion and Physicochemical Characteristics. Coatings 2021, 11, 587 https://doi.org/10.3390/coatings11 050587

Academic Editor: Jaejoon Han

Received: 8 March 2021

Accepted: 11 May 2021

Published: 17 May 2021

Publisher's Note: MDPI stays neutral with regard to jurisdictional claims in published maps and institutional affiliations.

Copyright: (c) 2021 by the authors. Licensee MDPI, Basel, Switzerland. This article is an open access article distributed under the terms and conditions of the Creative Commons Attribution (CC BY) license (https:// creativecommons.org/licenses/by/ $4.0 /)$.

\begin{abstract}
Polysaccharides have excellent potential as food-grade coating materials for microencapsulation in pro- and prebiotics-based functional food industry. In this study, potato, maize, and rice resistant starches composite coatings with D-mannose, maltodextrin, and whey protein concentrate were prepared for the spray-dried microencapsulation of Lactobacillus acidophilus KLDS 1.1003. Assessment of different polysaccharide coatings to enhance the longevity of probiotics at high temperatures of spray-drying process, storage, and targeted delivery in the gastrointestinal tract were the key objectives of the present study. The highest microencapsulation efficiencies were shown by maize $(95.80 \%)$ and potato $(94.30 \%)$ resistant starches. Similarly, maize resistant starch (MRS)-based composites provided the highest thermal resistance, with $\operatorname{Tg} 38.77 \pm 1.10-93.13 \pm 0.81{ }^{\circ} \mathrm{C}$ and showed the least $2.1 \log$ cycles viability loss in simulated GI tract. Viability losses during storage were in the following order: control > RRS > PRS > MRS, and the inactivation rate of the microencapsulated cells followed the first-order kinetics $\left(R^{2}=0.9264-0.9918\right)$. The resistant starch-based spray-dried microcapsules possessed $27.00 \pm 0.03$ to $52.28 \pm 1.02 \mu \mathrm{m}$ size range and SEM micrographs showed a unified smooth surface without cracks and ruptures. These findings will expand the potential use of natural food-grade coatings in functional foods and allied industries involving spray-dried products.
\end{abstract}

Keywords: polysaccharides; coating composites; probiotics; thermal protection; microcapsules; in vitro digestion; storage stability; morphology

\section{Introduction}

Functional foods provide nutrition and demonstrate specific targeted functions satisfactorily beneficial for improved health by reducing the risk of disease in the body [1]. Human eating lifestyles are driven by the food industry, which is continually searching for innovative ways to introduce bioactive compounds and microorganisms (probiotics) that play a pivotal role in sustaining better health in the human population [2]. According to the (WHO) World Health Organization and (FAO) Food and Agriculture Association of the United Nations, probiotics are defined as the 'living microorganisms which convey several health benefits to the host after administering in sufficient quantities' [3]. Probiotics are primarily driven from lactic acid bacteria (LAB) and are the fastest growing sector of the pharmaceutical, nutraceutical, and functional food industries [4]. The probiotic functionality to impart their beneficial effects to the host is closely related to their viability in minimum adequate amounts, i.e., $10^{6}-10^{7} \mathrm{CFU} / \mathrm{mL}$ or $\mathrm{g}$ of food [5]. The global significance of probiotics is increasing due to their health-maintaining nutritional and therapeutic 
values [6]. Health benefits include healthy gut microbiota, antimicrobial potentials [7-10], relief in constipation, boosting up the immune system [11,12], improving calcium absorption [13], synthesizing vitamins, prevention of diarrhea [14], Helicobacter pylori infection treatment, reduction in serum cholesterol levels, improvement in lactose tolerance levels, and protection from colon cancer [15]. However, their availability is compromised due to their sensitivity to acidic environments, severe heat treatment, humidity, mechanical processing, oxygen toxicity, food matrix physical state, storage temperatures, and adverse gastrointestinal conditions [16,17].

Lactobacillus acidophilus is amongst the most important commercial species of the Lactobacillus genus [18], which is normally added to probiotic functional foods like yoghurt, milk, toddler formula, and dietary supplements $[19,20]$. The optimum growth of $L$. acidophilus takes place at 40 to $42{ }^{\circ} \mathrm{C}$ but above $45^{\circ} \mathrm{C}$ it loses its viability during processing and storage [21]. This shortcoming limits its application in heat dried powder products [22]. According to a study, a variety of matrices related to polysaccharides and milk proteins can significantly protect the probiotic microorganisms through microencapsulation [23]. The cells remain entrapped within the microencapsulating material which favors bacterial viability throughout processing, storage, and gastrointestinal tract passage [24]. Microencapsulation (ME) is a process which provides a physical barrier around the microbes or active ingredients and improves their delivery in functional foods by providing protection against harsh environmental conditions throughout the processing and consumption periods $[25,26]$. Among the microencapsulation techniques spray-drying is a technique utilized on an industrial scale [27], but utilization of high temperatures causes thermal inactivation and simultaneous dehydration of probiotic microorganisms during the drying process which are key disadvantages in need of addressing [28].

Likewise, finding natural and effective coating materials for the spray-dried microencapsulation of probiotics, preserving their viability from harsh environments, is another main challenge in microencapsulation $[29,30]$. There increasing investigation of resistant starch (RS) matrices with thermos-protectants to formulate the prebiotic/probiotic (symbiotic) combinations for microencapsulation [29]. A small fraction of the starch, termed resistant starch (RS) escapes digestion in the small intestine by resisting pancreatic enzymes and is fermented in the large intestine by healthy microflora [31]. Utilization of RS for probiotics microencapsulation has dealt with numerous technological problems, e.g., thermal stability, increased shelf life, and targeted delivery [32,33].

Rice, maize, and potato resistant starches are starches with small granular size, containing high levels of resistant starch [34]. These starches have the capability to produce roundshaped microcapsules after spray drying. These spherical microcapsules facilitate the entrapment of probiotic bacteria and enhance their survivability [35]. Zanjani et al. [36] compared the rice and wheat starches for microencapsulation of probiotics and concluded that these starches enhanced the survival of L. casei ATCC39392. Similarly, Etchepare et al. [37] studied the high amylose maize starch in combination with thermoprotectant beads and found that the survivability of L. acidophilus La-14 was enhanced. Potato starch (PS) contains more amylopectin and resistant starch with phosphate groups, and it belongs to B-type crystallinity [33]. The advantage of high adherence capacity of Bifidobacterium strains to PS has been investigated by Crittenden et al. as well as for L. plantarum studied by Muhammad et al. [16,38,39].

Due to the higher chemical protection and molecular stability, polysaccharide and protein complexes have been considered effective as compared to single wall coating materials [37]. Steric stabilizing and thickening behavior of resistant polysaccharides and stabilizing characteristics of proteins provide stability to the microcapsule [38]. The whole milk protein inventory constitutes $20 \%$ of whey. Major components of whey proteins (WP) are $\beta$-lactoglobulin $(50 \%), \alpha$-lactalbumin $(20 \%)$, bovine serum albumin $(10 \%)$, and immunoglobulin $(10 \%)$, whereas lysozyme, lactoferrin, proteose, peptone, lactoperoxidase, and osteopontin are minor components [39]. Recently, the complexes of different polysaccharides with proteins have been studied, such as WP-gum Arabic [40], WP-beet pectin [41], 
and WP-high methoxyl pectin [42] for the microencapsulation process. Whey protein concentrate (WPC) been found favorable for delivering thermal protection during the spray drying process [43]. Detrimental effects of heat and osmotic stress on bacterial cells can be decreased by adjusting the drying carrier media [44]. Sugars maintain the unique structure of membrane's lipid bilayer; chemical reaction among sugars and cellular membranes thus reduce the osmotic stress on bacteria, hence provide thermal protection during the dehydration process [45]. Integration of lower molecular weight sugars like trehalose and polyols, and mono sugars like a-D glucose and mannose in drying carrier media can serve the purpose $[16,25]$.

There are very few available studies which provide information about the comparative utilization of different resistant starches such as rice, maize, and potato resistant starches with combinations of heat protecting agents as food-grade coating materials for spraydried microencapsulation to produce stabilized powders containing probiotics. In addition, the aim of our study is to encourage the utilization of resistant starch-based natural coating matrices with heat protecting agents and investigate the effect of these coating matrices and their physicochemical attributes associated with probiotics survivability during spray drying process, storage, and simulated gastrointestinal (GI) conditions.

The underlying hypothesis of the current study was that the coating composites of resistant starches with heat protecting agents (WPC, maltodextrin, D-mannose) could additionally protect the probiotics against elevated spray drying temperatures, digestion, and storage. Assessment of three polysaccharides, i.e., potato resistant starch (PRS), maize resistant starch (MRS), and rice resistant starch (RRS) as potential coating materials containing L. acidophilus KLDS 1.1003 was carried out. The effect of these coating formulations on the viability of probiotic cells after spray drying and in vitro digestion upon storage and physicochemical properties of obtained dried powders were investigated. This study could be an innovative idea to introduce resistant starches as biobased and natural polymeric coating materials for microencapsulation and survival of probiotics during spray-drying heat processes in functional foods, nutraceutical, and pharmaceutical products.

\section{Materials and Methods}

The LAB strain Lactobacillus acidophilus KLDS 1.1003 was isolated from traditional yogurt in Inner Mogolia, China and identified by $16 \mathrm{~S}$ rRNA gene similarity analysis and API $50 \mathrm{CH}$ strips. The bacteria were stored at the Key Laboratory of Dairy Science (KLDS), Ministry of Education, China. RRS (rice resistant starch, PubChem ID 24899737), MRS (maize resistant starch PubChem ID 24899847), PRS (Potato resistant starch PubChem ID 24899595), D-mannose (PubChem 24897068), maltodextrin 15 DE (PubChem: 62698), and lactic acid (PubChem ID 24855212) were procured from Sigma Aldrich Mainland, China. Spray dried whey protein concentrate (WPC-80) was procured from College of food Science and Technology, Huazhong Agricultural University, Wuhan-China, containing protein $=80 \%$, lactose $=4 \%$, fat $=4 \%$, ash $=3 \%$ and total moisture $=3.5 \%$. Pancreatin from porcine pancreas (Sigma P1750), pepsin from porcine gastric mucosa (Sigma P6887, 3200-4500 U/mg), and ox-bile (Sigma 70168) were procured from Sigma-Aldrich (Shanghai, China). All other supplemental chemicals were of analytical grade.

\subsection{Preparation of Cell Cultures}

de Man Rogosa Sharpe broth (MRS-broth) was used for the reactivation of the frozen stock culture of the L. acidophilus KLDS 1.1003. Reactivation of the culture was carried out twice. Inoculation of the $25 \mathrm{~mL}$ of the culture was carried out successively in MRS-broth $(500 \mathrm{~mL})$ of and incubation was done for $16 \mathrm{~h}$ until stationary phase. Cell pallets were collected by centrifugation for ten minutes at $10,000 \times g$ and $4{ }^{\circ} \mathrm{C}$. Thermo Sorvall Legend Micro, 21 micro centrifuge machine was used for the centrifugation purpose. The pellets were washed three times and were suspended in pre-sterilized distilled water. 


\subsection{Formulations of Coating Composites for Spray-Drying}

Freshly harvested L. acidophilus KLDS 1.1003 were taken as core and their culture preparation procedure has been described in above Section 2.1. The control medium was prepared by dispersing $5 \mathrm{~g}$ of WPC, $15 \mathrm{~g}$ of maltodextrin, and $5 \mathrm{~g}$ of D-mannose in sterilized water with a continuous stirring for sixty minutes. The other formulations containing $10 \mathrm{~g}$ of PRS (potato resistant starch, RRS (rice resistant starch) and MRS (maize resistant starch) were separately heated at $75^{\circ} \mathrm{C}$ for ten minutes. The resistant starch-based suspensions were stirred with a magnetic stirrer during the whole process and cooled up to $25^{\circ} \mathrm{C}$. 6 pellets of L. acidophilus KLDS 1.1003 were mixed into each resistant starch-based suspension and then equal volume of control medium was combined with each suspension separately. The composition of all solutions has been described in Table 1. High pressure homogenizer (APV 2000, Munich, Germany) was used at $7000 \mathrm{rpm}$ for $60 \mathrm{~s}$ afore from spray drying process. Sterilized glass wares were used during the whole trial, and sterilization was done at $121^{\circ} \mathrm{C}$ for $15 \mathrm{~min}$.

Table 1. Resistant starch-based coating formulations $(\% w / w)$ for microencapsulation of L. acidophilus KLDS 1.1003 for spray drying.

\begin{tabular}{ccccc}
\hline Materials & Control & PRS ME & RRS ME & MRS ME \\
\hline Potato resistant starch (g) & - & 10 & - & - \\
Rice resistant starch (g) & - & - & 10 & - \\
Maize resistant starch(g) & - & - & - & 10 \\
Maltodextrin (g) & 15 & 15 & 15 & 15 \\
Whey protein concentrate (g) & 5 & 5 & 5 & 5 \\
D-manose (g) & 5 & 5 & 5 & 5 \\
Total solid (\%) & 25 & 35 & 35 & 35 \\
pH & 6.50 & 6.30 & 6.28 & 6.26 \\
\hline
\end{tabular}

PRS ME = Potato resistant starch microencapsulation; RRS ME = Rice resistant starch microencapsulation MRS ME = Maize resistant starch microencapsulation .

\subsection{Spray-Dried Microencapsulation Process and Storage of Powdered Composites}

Lab-scale Buchi spray dryer (B-290, Flawil, Switzerland) was used for microencapsulation of L. acidophilus KLDS 1.1003 using carrier mediums containing different resistant starches by using the method described by Muhammad et al. [16]. Following conditions were used to operate the spray dryer. Continual inlet $\left(120 \pm 2^{\circ} \mathrm{C}\right)$ and outlet $\left(60 \pm 3^{\circ} \mathrm{C}\right)$ temperatures, feeding rate $\left(7 \mathrm{~mL} \cdot \mathrm{min}^{-1}\right)$, air pressure $(0.3 \mathrm{MPa})$, and the drying air flow rate $\left(25 \mathrm{~m}^{3} \cdot \mathrm{h}^{-1}\right)$, respectively. A continuous stirring of all formulations was carried out with the help of magnetic stirrer and pumped into the spray chamber. The powdered microcapsules were collected from the cyclone bottom of the dryer. All dried powdered formulations were put in airtight glass vials. The vials were sealed in an aluminum foil and kept in desiccators having saturated lithium chloride $(\mathrm{LiCl})$ solution $(\mathrm{aw}=0.11)$ and kept into an incubator at $25^{\circ} \mathrm{C}$ till further microbiological, technological, in vitro digestion, and morphological analyses.

\subsection{Storage Perseverance of Resistant Starch-Based Microencapsulated L. acidophilus KLDS 1.1003}

Assessment of viability of resistant starch-based microencapsulated L. acidophilus KLDS 1.1003 was carried out during storage period of forty-two days at ambient $\left(25^{\circ} \mathrm{C}\right)$ temperature by enumerating on MRS-agar. The spray dried powder $(0.1 \mathrm{~g})$ was dissolved in peptone water. The powder was allowed to dissolve for 20-30 $\mathrm{min}$, and then serial dilutions were prepared. $0.1 \mathrm{~mL}$ aliquot was plated and incubated for $48 \mathrm{~h}$ at $30^{\circ} \mathrm{C}$ on MRS agar. The viability assessment of encapsulated L. acidophilus KLDS 1.1003 throughout storage was done by calculating the logarithmic values $\left(\log N_{t} / N_{o}\right)$ of the comparative cell viability against storage time. A first order reaction kinetics model described by Lapsiri 
et al. [46] was used for the viability assessment by putting logarithmic values in given Equation (1).

$$
\log N_{t} N_{o}=-k_{T} t
$$

where $N_{t}$ stands for viable bacteria (in CFU/g) at a certain storing time, $N_{o}$ symbolizes the quantity of viable cells (in CFU/g) in the beginning of the storage, and $t$ represents the time (in days) for storage. Whereas, $k_{T}$ indicates the rate of viability loss (per day) at $25^{\circ} \mathrm{C}$.

\subsection{Microencapsulation Efficiency of Coating Materials}

According to Ayama et al. [47] the encapsulation efficiency (EE\%) of the microcapsules has been defined as the number of viable cells encapsulated in the microcapsules compared with the number of viable cells taken to form microcapsules and it is calculated by using the following equation.

$$
\text { Encapsulation efficiency }(\%)=\frac{\text { No. of viable cells encapsulated in capsules }}{\text { No. of viable cells taken to form capsules }} \times 100
$$

\subsection{Survivability of Microencapsulated L. acidophilus KLDS 1.1003 during Simulated Gastrointestinal Conditions}

Microencapsulated bacteria in spray dried formulations and free cell bacteria (FCB) were analyzed to compare their competence to persist in vitro digestion simulating the human gastric and intestinal conditions. Assessment of survivability of microencapsulated bacteria during simulated gastrointestinal conditions was done by using the method as describe by Mariana et al. [37] with slight modifications to make a better resemblance to the duodenal bile salt concentration $(4.4 \mathrm{~g} / \mathrm{L})$ and gastric pepsin activity $(1600 \mathrm{unit} / \mathrm{mL})$ found in human aspirates. Next, $0.3 \mathrm{~g}$ of spray dried micro particles were suspended in saline $(2.5 \mathrm{~mL})$ in $30 \mathrm{~mL}$ glass vials and then $(2.5 \mathrm{~mL})$ simulated gastric juice (double concentrated) was added ( $\mathrm{pH}$ 2.5, $7.2 \mathrm{mmol} / \mathrm{L} \mathrm{CaCl}_{2}, 3200 \mathrm{unit} / \mathrm{mL}$ pepsin, $98 \mathrm{mmol} / \mathrm{L} \mathrm{NaCl}, 3 \mathrm{mmol} / \mathrm{L}$ $\mathrm{MgCl}_{2}, 12.8 \mathrm{mmol} / \mathrm{L} \mathrm{KH}_{2} \mathrm{PO}_{4}$ and $24 \mathrm{mmol} / \mathrm{L} \mathrm{KCl}$ ) [48]. Screw capping of the vials was done under a stream of nitrogen $\left(\mathrm{N}_{2}\right)$ and after being screw capped the vials were incubated for $1 \mathrm{~h}$ at $37^{\circ} \mathrm{C}$ with a continuous magnetic stirring ( $130 \mathrm{rpm} /$ minute) for gastric digestion. Bile salts and pancreatin were dissolved $\mathrm{NaHCO}_{3}(0.1 \mathrm{~mol} / \mathrm{L})$ and added to the gastric digesta, and incubated for $2 \mathrm{~h}$. The serial dilutions of aliquots of the digesta were made by using phosphate buffer solution (PBS) and enumeration of viable bacteria of each vial was done after being platted on MRS-agar, as described earlier. Counts were performed after $30,60,90$, and $120 \mathrm{~min}$ of incubation. Survival ratios were calculated before and after the simulated digestion $\left(\log N / N_{o}\right)$.

\subsection{Characteristics of Powders Coated with Starch Composites}

\subsubsection{Water Activity}

An Aqualab water activity meter (Aqualab, Model Series 3 TE, Meter Group, Washington, DC, USA) was used to determine the water activity $\left(\mathrm{a}_{\mathrm{W}}\right)$ of spray dried formulation powders.

\subsubsection{Moisture Content}

AOAC method was followed to determine the moisture contents (\%) of all the samples of powdered formulations [49]. The $2 \mathrm{~g}$ of each type of powder was taken and drying was done at $105^{\circ} \mathrm{C}$ until a constant weight was attained.

\subsubsection{Hygroscopicity}

One gram $(1 \mathrm{~g})$ of microencapsulated dry powder of each formulation was used to determine the hygroscopicity. The hygroscopicity was calculated gravimetrically by following the method as described by Fritzen-Freire et al. [50] over a 7-day period by maintaining $75 \%$ relative humidity $(\mathrm{RH})$ in a desiccator. The desiccator contained a saturated solution of $\mathrm{NaCl}$ at ambient $25{ }^{\circ} \mathrm{C}$. 


\subsubsection{Differential Scanning Calorimetry (DSC) Analyses}

All microencapsulated formulations were analyzed for glass transition temperatures by using the differential scanning calorimeter (DSC-6 Perkin Elmer, Ltd., Beaconsfield, UK) by following the method described by Lv et al. [51] with some modifications. About $15 \mathrm{mg}$ (dry basis) of each sample was weighed into aluminum DSC pans and the pans were sealed by using DSC pan sealer. After sealing, the pans were equilibrated at $25^{\circ} \mathrm{C}$ for $2 \mathrm{~h}$. Then the heating of sample pans was done from $-30^{\circ} \mathrm{C}$ to $150{ }^{\circ} \mathrm{C}$ at a heating rate of $10^{\circ} \mathrm{C} /$ minute under a nitrogen atmosphere with a flow rate of $50 \mathrm{~mL} / \mathrm{m}$. A pre-weighed empty pan was taken as reference. A double heating-cooling scanning step was performed before calculating the onset, midpoint, and end glass temperature.

\subsubsection{Particle Size Analyses}

Particle size calculation of dried powders was done by using the Mastersizer 2000 (Malvern Instruments, Worcestershire, UK) which was equipped with the Hydro 2000S dispersion unit. Dispersion of each powdered sample $(0.5 \mathrm{~g})$ was done in water $(5 \mathrm{~mL})$ at ambient temperature $\left(25 \pm 2{ }^{\circ} \mathrm{C}\right)$ then dispensed into the dispersion unit. Mie theory was used to calculate the mean particle size diameters $\left(\mathrm{d}_{\mathrm{v}, 90}\right)$ of each type of microcapsules [52].

\subsubsection{Morphological Characteristics}

A scanning electron microscope (SEM, Hitachi S-3400 N, Hitachi Ltd., Tokyo, Japan) was used to study the morphological characteristics of spray dried powdered microcapsules by following the method as described by Muhammad et al. [16]. A small amount of the dried powder samples was put on SEM metallic stub and covered by adhesive tape. Then these samples were gold coated with gold-palladium by a sputter coater. The representative micrograph images were taken at $10 \mu \mathrm{m}$ resolution and $10 \mathrm{~Pa}$ vacuum pressure, with an accelerating voltage of $5-15 \mathrm{kV}$.

\subsection{Statistical Analyses}

All of the above mentioned experiments were performed on microencapsulated $L$. acidophilus KLDS 1.1003 and spray dried powders of all formulations obtained from spray drying and where needed, the tests were performed in triplicates. Analysis of variance (ANOVA) of the water activity, hygroscopicity, moisture content, particle size, glass transition temperature, viable counts during storage, and survival in simulated gastrointestinal conditions, corresponding to the dried powders and the data obtained, was subjected to statistical analyses using Statistix 8.1 (Analytical Software, USA). Tukey test was used to compare treatment means at $p<0.05$.

\section{Results and Discussion}

\subsection{Efficiency of Encapsulation (\%)}

The results of our study show the viability of L. acidophilus KLDS 1.1003 after microencapsulation and encapsulation efficiency (EE\%) of micro capsules which were produced with a combination of resistant starches and different thermo protectants. The bacterial viability in all formulation particles was greater than the minimal recommendations $\left(6.0 \log \mathrm{CFU} / \mathrm{g}^{-1}\right)$ [3]. Among the encapsulating matrices studied, MRS and PRS yielded the best viability of L. acidophilus 1.1003; however, non-significant difference ( $p>0.05)$ was noted between them. Owing to enhanced viability, these two encapsulating matrices provided the greatest survival rates, of $95.80 \%$ and $94.31 \%$, respectively, followed by RRS $(86.95 \%)$ as shown in Table 2.

The encapsulation efficiency (EE) refers to the potential of coating materials to hold or encapsulate the core materials within the microcapsule and it is among the salient characteristic of wall materials [53]. The film-forming capability of starches provide further protection to the core material and this ability makes starches a good choice for microencapsulation $[25,54]$. Several technological problems like thermal stability, controlled release, and longer shelf life of biologically active and sensitive molecules has been 
tackled with the use of resistant starches, especially in case of probiotics microencapsulation [26,37]. Additionally, extra protection is provided to the probiotics when resistant starch is used in combination with other polysaccharides by promoting synergistic effects on gelation, as well as imparting a prebiotic effect by producing particles with integrated structure $[26,55]$. These valuable features make these encapsulating matrices an alternative to gum arabic, which is mostly utilized in spray drying for microencapsulation of food components $[25,37]$.

Table 2. Particle size distribution (span, diameter), microencapsulation efficiency (EE), and inactivation rate $\left(R^{2}\right)$ throughout 42 -days storage at $25^{\circ} \mathrm{C}$ of control and resistant starch-based microencapsulated L. acidophilus KLDS 1.1003.

\begin{tabular}{ccccc}
\hline Treatment & Span & Diameter $(\mathbf{0 . 9} \boldsymbol{\mu m})$ & EE (\%) & $\boldsymbol{R}^{\mathbf{2}}$ \\
\hline Control & $2.43 \pm 0.01^{\mathrm{b}}$ & $27.00 \pm 0.03^{\mathrm{d}}$ & $79.90^{\mathrm{d}}$ & $0.9264^{\mathrm{d}}$ \\
PRS & $1.99 \pm 0.02^{\mathrm{d}}$ & $47.42 \pm 0.80^{\mathrm{b}}$ & $94.30^{\mathrm{b}}$ & $0.9908^{\mathrm{b}}$ \\
RRS & $2.39 \pm 0.02^{\mathrm{c}}$ & $41.55 \pm 0.15^{\mathrm{c}}$ & $86.95^{\mathrm{c}}$ & $0.9892^{\mathrm{c}}$ \\
MRS & $3.44^{\mathrm{b}} \pm 0.05^{\mathrm{a}}$ & $52.28 \pm 1.02^{\mathrm{a}}$ & $95.80^{\mathrm{a}}$ & $0.9918^{\mathrm{a}}$ \\
\hline
\end{tabular}

Data expressed as mean \pm standard deviation. Significant variance is shown by different letters within individual rows rendering to Tukey means post comparison test $(p<0.05)$.

Nunesa et al. [25] found that, the best viability of L. acidophilus s La-5 was produced by inulin and hi-maize resistant starch. The greatest survival rates were $93.12 \%$ and $94.26 \% \mathrm{ob}-$ tained from these two encapsulating materials respectively, followed by 89.68\% (gum Arabic) and $90.34 \%$ (trehalose). Similarly, combinations of different encapsulating agents (corn starch, glucose, oil, and protein) for spray drying were studied by Ying et al. [56] for the protection of L. rhamnosus GG. They discovered that combining resistant starch with encapsulating agents efficiently protected the microbes. That is why starches are being employed widely for microencapsulation materials [57]. The mechanism to provide protection might be associated with the helical structure of amylose which have the ability to encompass other molecules to form highly stable complexes with these molecules [58]. In another study Rajam and Anandharamakrishnan [59] investigated how the addition of fructo-oligosaccharides and galacto-oligosaccharides to whey protein isolates and maltodextrin systems increased the viability of Lactobacillus plantarum after spray drying. Bustamante et al. [60] used encapsulating agents which is the mixture of linseed mucilage, chia seed, and soluble protein of chia seed for microencapsulation of the Lactobacillus plantarum, and concluded linseed mucilage efficiency was $88.25 \%$. Arslan et al. [61] used numerous wall materials (modified starch, WPC, gelatin, maltodextrin, acacia, and isolated pea proteins) to for the microencapsulation of Saccharomyces cerevisiae var. Boulardi., reporting $84.69 \%$ to $91.81 \%$ efficiency. The higher survivability of microorganisms in the present research work could be related to the concentration $(20 \% \mathrm{~m} / \mathrm{v})$ and type of microencapsulating matrices. The feed solution solid concentration $(20-30 \% \mathrm{~m} / v)$ is among the best conditions ensuring higher viability of the bacteria [62]. Resistant starch can be chosen as a potential prebiotic encapsulating wall material for probiotics, which beneficially promote and protect their growth [63]. Mirzaei et al. [64] also studied microencapsulated L. acidophilus in resistant starch and calcium alginate gel, and found similar results. Sultana et al. [65] also observed the increased storage stability of microencapsulated bacteria by using high maize starch and alginate combinations by emulsification. Further, Etchepare et al. [48] used the extrusion method for microencapsulation of Lactobacillus acidophilus L-14, using alginate alone as well as alginate hi-maize combinations and reported the similar results.

According to findings of Pitigraisorn et al. [66] after exposing the protein-starch complexes to moist heat the starch granules absorbed moisture from the protein matrix, which led to an increase in protein-starch interactions and apparently increased the protein concentration. This mechanism substantially increased the gel strength of the composite, resulting higher tolerance against moist-heat. The study conducted by 
Corona-Hernandez et al. [67] supported the explanation, by showing that the viscoelastic properties were important factor to determine the thermo tolerance levels of microcapsules of polymer-protein complexes. Microcapsules should contain adequate numbers of microorganisms to be incorporated in foods. Usually, the reduction in number of microorganisms' population lower than 2 logarithmic cycles but larger than $\times 10^{7} \mathrm{CFU} / \mathrm{g}$ is required [68]. Normal range of encapsulation efficiency for probiotics is taken between $60-95 \%$ [69]. However, 90\% (EE) value has barely been reported. The spray drying encapsulation technique can be used to explain these results, like, Lopez-Rubio and Lagaron [70] reported that utilizing electro-spraying microencapsulation technique could significantly improve the EE of probiotics.

\subsection{Survivability of Composite-Based Microencapsulated Bacteria in Simulated GI Conditions}

The key characteristic of probiotics to be incorporated effectively into functional foods is their ability to withstand the digestive strains [23]. The viability of probiotics is noticeably increased due to the protection provided by the biopolymers as microencapsulating coating materials [71].

The effect of simulated GI (gastrointestinal) digestion conditions on the comparative cell survival of free bacteria collected from MRS-broth and spray dried microencapsulated L. acidophilus KLDS 1.1003 was assessed and their $\log$ transformed ratios $\left(\log N / N_{o}\right)$ are given in Figure 1. MRS and PRS-based microencapsulated formulations showed a highly significant $(p<0.001)$ better protection to L. acidophilus KLDS 1.1003 during the simulated digestion, while the survival ratios were lesser in control and free cell bacteria.

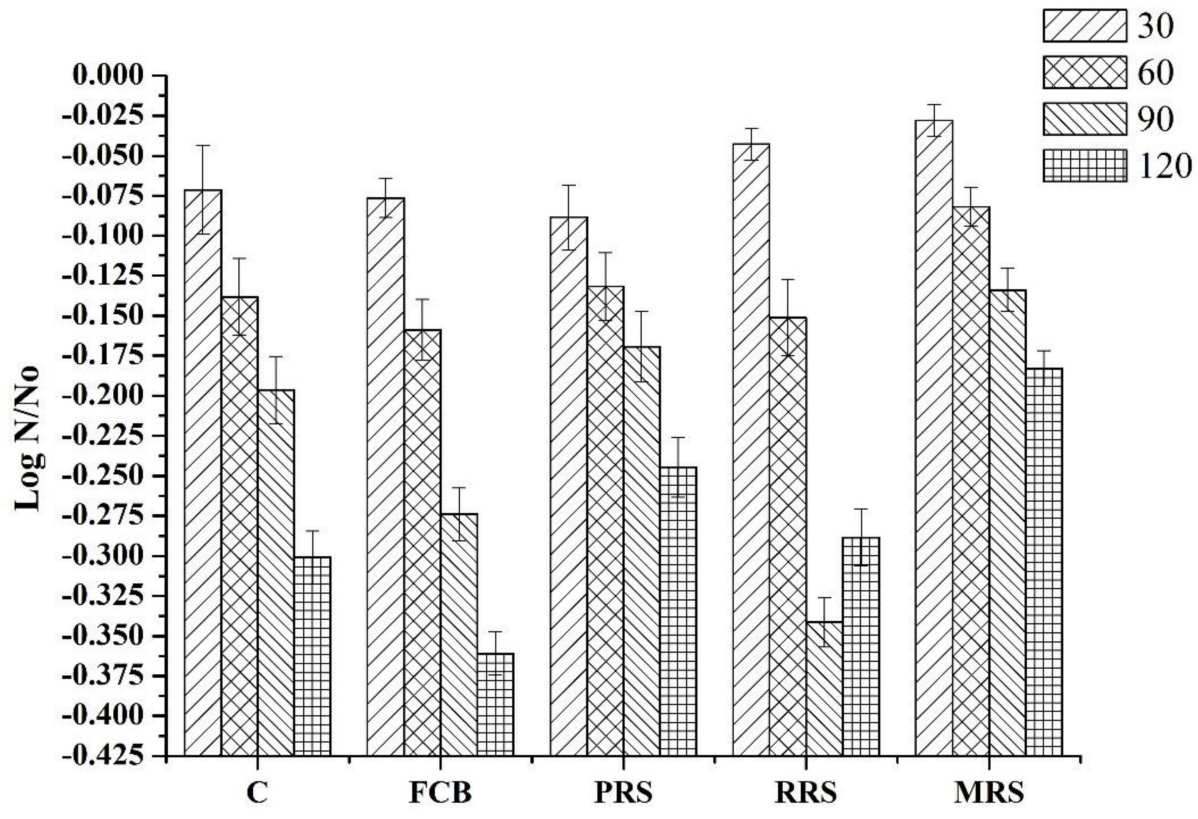

Figure 1. Survival of free and coating-based microencapsulated L. acidophilus KLDS 1.1003 after in vitro digestion. Bars express the mean value of log transformed ratio of bacterial counts, before and during the simulated digestion for $2 \mathrm{~h}$ with $30 \mathrm{~min}$ interval. At the start of in vitro digestion reaction vials contained: control (C) $6.6 \pm 0.33 \log \mathrm{CFU}$; free cell bacteria (FCB) $6.2 \pm 0.28 \log \mathrm{CFU}$; potato resistant starch (PRS) $6.5 \pm 0.33 \log$ CFU; rice resistant starch (RRS) $6.4 \pm 0.29 \log$ CFU; maize resistant starch (MRS) $6.3 \pm 0.32 \log$ CFU.

In the simulated gastrointestinal tract, the free-cultured and control L. acidophilus KLDS 1.1003 showed a loss of 3.5 and $3.3 \log$ cycles, respectively. While the microencapsulated particles ranged from a loss of 2.8 to $2.1 \mathrm{log}$ cycles in relation to the initial counts. Resultantly, the studied microparticles gave protection to microencapsulated bacteria, whereas, free culture faced significant losses. These results are supported by a study conducted by Gebara et al. [72]. According to this study, an increased resistance and survivability was 
observed after exposing the microencapsulated probiotics against simulated gastrointestinal conditions as compared to the free cells. MRS showed the highest protection for $L$. acidophilus KLDS 1.1003, compared to control, PRS and RRS.

While for gastrointestinal study, the Pankasemsuk et al. [73] used the emulsion technique for microencapsulation of Lactobacillus casei by using hi-maize resistant starch and reported that the highest protection and promotion of bacterial viability was shown by the bacteria microencapsulated with corn starch when exposed to both gastric and biliary fluids. In addition, Etchepare et al. [48] microencapsulated L. acidophilus using sodium alginate alone and in combinations of hi-maize resistant starch by using extrusion technique and found that hi-maize-based microcapsules showed the greatest resistant to simulated GI conditions. The findings of our study are supported by the correlated results reported in previous research works. RRS showed the lowest cell survival ratio among the microencapsulated treatments. It might be because of its poriferous and water soluble nature, resulting an entire release of bacterial cells into harsh gastric conditions causing a significant decrease in viability [34]. Maize resistant starch-based micro capsules enclosing bacterial cells showed better cell survival after $2 \mathrm{~h}$ incubation in gastric medium than other formulations. The ability of resistant starches to provide protection against gastric conditions might be due to their characteristic of forming less soluble films compared to other wall materials. Due to this ability the MRS and PRS-based powders are slowly rehydrated and the water inflow through the cell membranes decreases, which results in a slower release of microencapsulated bacteria in simulated GI atmosphere [74]. According to some studies rice bran and resistant starches produced beads with a superior integrated structure and imparted prebiotic effects to lactic acid bacteria in particular $[75,76]$.

These findings prove that maize resistant starch (MRS) provides a better protection to L. acidophilus KLDS 1.1003 cells against GI environments compared to other resistant polysaccharides investigated in our study. The control formulation having no resistant starch and the free cell bacteria which were not exposed to spray drying exhibited the same survival ratios. The free cell bacteria had not been exposed to spray drying, while cells in the control medium survived the drying process because the thermo protecting ingredients protected them against heat-induced sub-lethal injuries [77].

\subsection{Effect of Coating Composites on Storage Stability of L. acidophilus KLDS 1.1003 in Spray-Dried Powders at $25^{\circ} \mathrm{C}$}

The bacterial count of viable L. acidophilus KLDS 1.1003 enclosed in spray dried microparticles and stored for 42 days at $25^{\circ} \mathrm{C}$ is shown in Figure 2. The initial probiotic counts of the spray-dried microcapsules were $8.00 \pm 0.40,8.60 \pm 0.29$, and $8.30 \pm 0.41 \log \mathrm{CFU} \mathrm{g}^{-1}$ for the PRS, MRS, and microparticles containing RRS, respectively.

These microparticles were generated by spray drying with optimized set conditions and a storage study was conducted for 42 days at $25^{\circ} \mathrm{C}$ without fixing $\mathrm{RH}$. Then the impact of polysaccharide-based matrices and physical states on the storage stability and viability of probiotics was assessed. The initial probiotic cells range of about 7.8 $\pm 0.30-8.6 \pm 0.29 \log$ CFU/g) of free and microencapsulated L. acidophilus KLDS 1.1003 cells was taken as shown in Figure 2. The decline in viability of probiotics occurs due to the lipid oxidation of membrane and this oxidation is crucially influenced by factors like temperature and residual moisture content during storage [78]. The inactivation rate of microencapsulated L. acidophilus KLDS 1.1003 cells followed first-order kinetics, shown in Table 2 $\left(R^{2}=0.9264-0.9918\right)$ during storage, has successfully been used by other experts [79,80].

The mixture of WPC, maltodextrin and D-mannose was taken as our control. In the present study, significantly $(p<0.01)$ different inactivation rates of L. acidophilus KLDS 1.1003 in powders stored at $25^{\circ} \mathrm{C}$ for 42 days were in the following order: control $>$ rice resistant starch > potato resistant starch > maize resistant starch. Free or non-encapsulated bacteria declined viability $7.82 \pm 0.30$ to $2.5 \pm 0.13 \log \mathrm{CFU} / \mathrm{g}$ as compared to MRS-based microencapsulated bacteria $(8.6 \pm 0.29-4.1 \pm 0.35 \log \mathrm{CFU} / \mathrm{g})$ and RRS $(8.3 \pm 0.41-3.6 \pm 0.18 \log \mathrm{CFU} / \mathrm{g})$. It might be correlated with the glassy state of the biomicrocomposite, because it has been verified by several studies that an amorphous glassy state of biomicrocomposites is imper- 
ative for the survival of bacteria during the storage period [81-83]. Similarly, the storage stability is also influenced by the combined effect of moisture content and glass transition temperature of the microparticles. Changes in moisture content were observed due to the transition of microparticles from rubbery to glassy state during storage period. This phenomenon effected the storage stability as these changes can be seen in Figure 3B and Table 3 respectively [84].

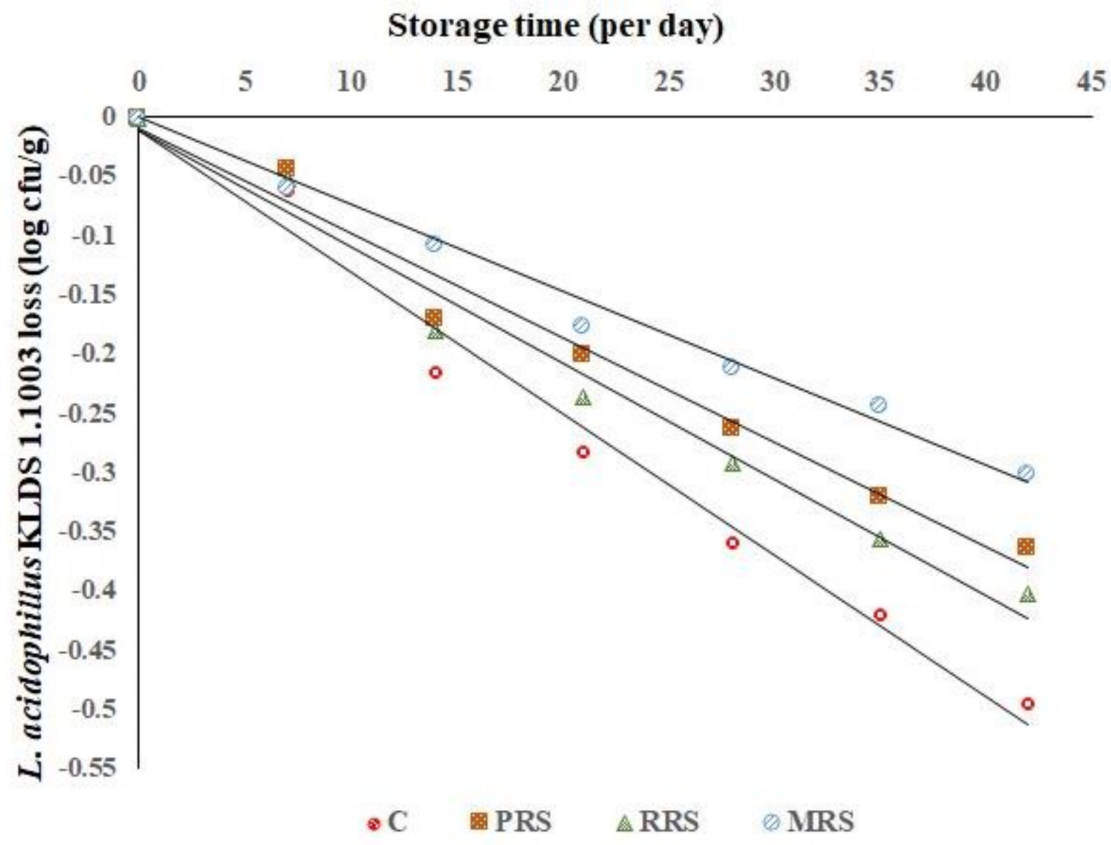

Figure 2. Loss in viability of starch coating-based spray-dried and microencapsulated L. acidophilus KLDS 1.1003 at $25^{\circ} \mathrm{C}$ storage temperature, presented as a function of storage period, (day). The rate constant $\mathrm{k}$ was obtained by linear regression analysis.

The process of microencapsulation has proven its worth to increase the microbial viability by protecting them against unfavorable storage conditions. The essential survivability or viability of probiotics is the vital criteria for their incorporation in functional foods during production and shelf life of these products. The effects of microencapsulation protection on the survival of probiotics by using different biopolymers have been studied by several researches. These research works showed that the viability of microencapsulated probiotics was significantly enhanced as compared to non-encapsulated bacteria during processing and storage, when these bacteria were microencapsulated with polymers and their combinations with other materials $[85,86]$.

Hugo et al. [87] studied the microencapsulation of Lactobacillus plantarum CIDCA 83,114 by using carrier mediums containing galacto-oligosaccharides and observed the improvement in viability during storage. Etchepare et al. [48] also found the similar decreasing trend in loss of viability of L. acidophilus La-5 after using hi-maize resistant starch for microencapsulation material as compared to our study result. Correspondingly, hi-maize, inulin, and trehalose were used thermal protectant in another study for the spray dried microencapsulation of L. acidophilus where they provided protection during the storage study [25]. The microencapsulating materials reduced the perviousness of spray dried particles and created a physical insulation between bacteria and the external environment which resulted in improvement in heat tolerance and increased capability against drying and storage conditions [73,88].

\subsection{Thermo Physical Properties of Starch-Based Spray Dried Powder}

Onset $\left(\mathrm{Tg}_{\mathrm{o}}\right)$, mid $(\mathrm{Tg})$ and end points $\left(\mathrm{Tg}_{\mathrm{e}}\right)$ are the aspects related glass transition temperature attributes are presented in Table 3 and these were determined by using DSC 
thermographs. During storage, glass transition temperature (Tg) is vitally important for spray dried products, because the characteristics of these products e.g., collapse of pores and the changes in texture and rehydration capabilities, physical stability (caking and adhesiveness), and biochemical reactions (based on enzymatic reaction color or texture modifications and lipid oxidation) are directly linked to glass transition temperature $[84,89]$.

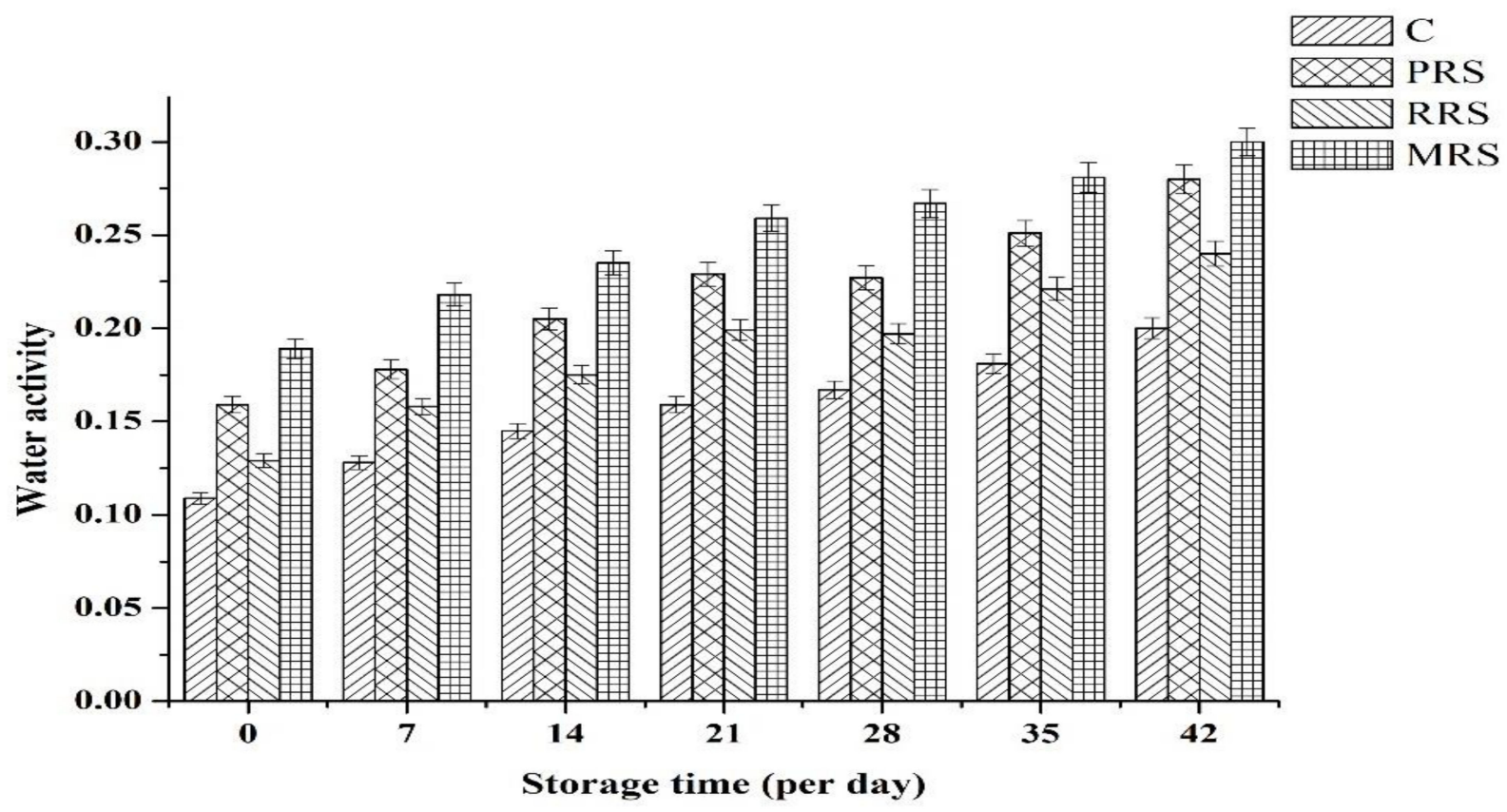

(A)

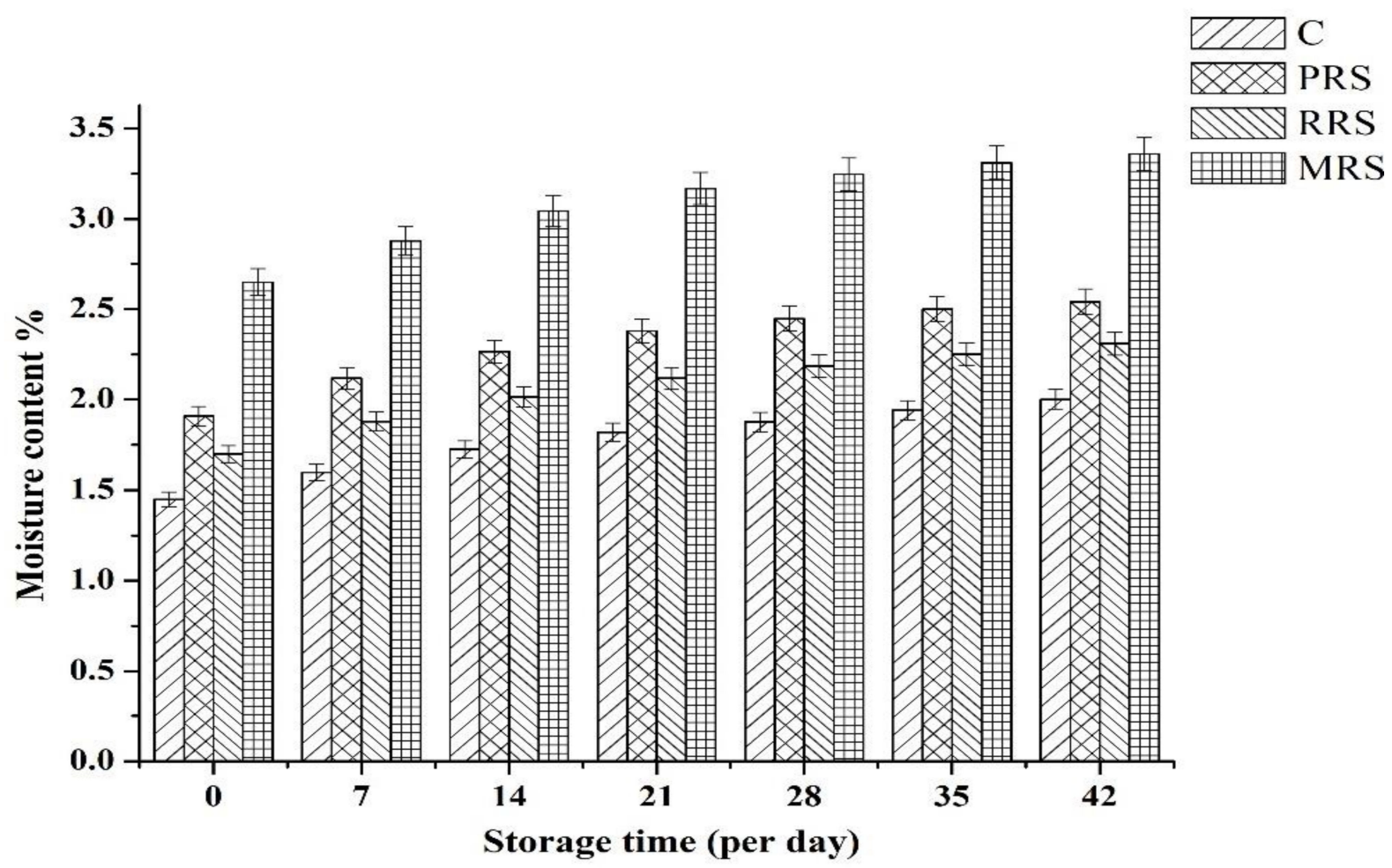

(B)

Figure 3. Cont. 


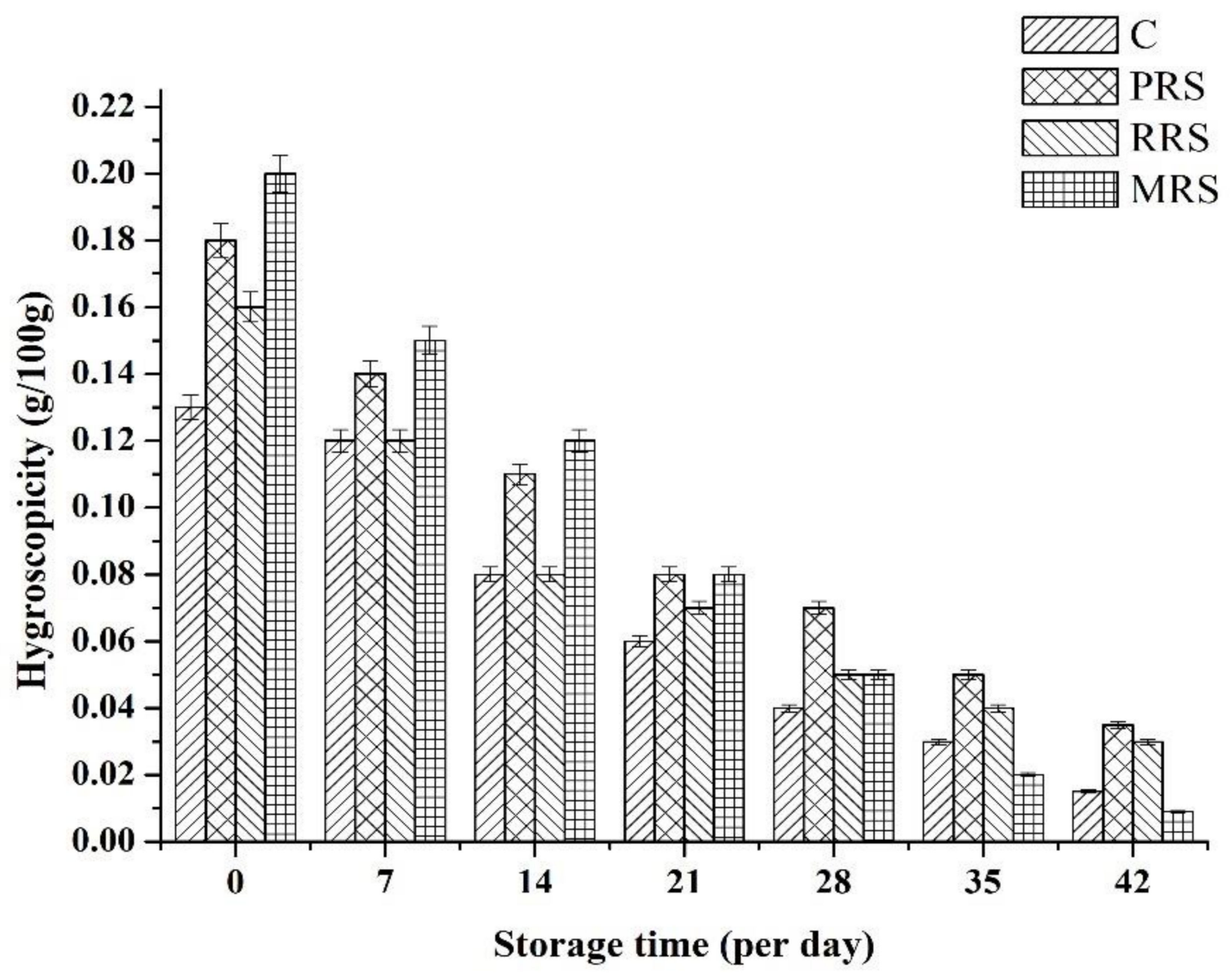

(C)

Figure 3. Effect of the resistant starch coatings on physical properties of the spray-dried powders enclosing L. acidophilus KLDS 1.1003 at $25{ }^{\circ} \mathrm{C}$ during 42 day storage. (A): water activity; (B): moisture contents (\%), and (C): hygroscopicity (g/100 g).

Table 3. Effect of the resistant starches and thermo protectants-based coatings on glass transition temperatures of the spray-dried composite powders containing L. acidophilus KLDS 1.1003.

\begin{tabular}{cccc}
\hline Treatment & Tg $_{\mathbf{o}}$ & $\mathbf{T g}_{\mathbf{m}}$ & Tg $_{\mathbf{e}}$ \\
\hline Control & $50.08 \pm 0.98^{\mathrm{a}}$ & $75.77 \pm 0.74^{\mathrm{a}}$ & $101.46 \pm 0.24^{\mathrm{a}}$ \\
PRS & $40.76 \pm 0.43^{\mathrm{c}}$ & $69.12 \pm 0.95^{\mathrm{c}}$ & $96.48 \pm 0.56^{\mathrm{c}}$ \\
RRS & $48.07 \pm 0.64^{\mathrm{b}}$ & $71.98 \pm 0.69^{\mathrm{b}}$ & $97.89 \pm 0.48^{\mathrm{b}}$ \\
MRS & $38.77 \pm 1.10^{\mathrm{d}}$ & $65.95 \pm 0.86^{\mathrm{d}}$ & $93.13 \pm 0.81^{\mathrm{d}}$ \\
\hline
\end{tabular}

Data expressed as mean \pm standard deviation. Significant variance is shown by different letters within individual rows rendering to Tukey means post comparison test $(p<0.05)$.

Our results indicate that the rubbery to glassy state transition $\left(\mathrm{Tg}_{\mathrm{o}}\right)$ temperature of the MRS and PRS-based microencapsulated powders were considered significant as they displayed significantly $(p<0.05)$ lower values $\left(38.77 \pm 1.10\right.$ to $\left.40.76 \pm 0.43{ }^{\circ} \mathrm{C}\right)$ respectively, as compared to control $\left(50.08 \pm 0.98^{\circ} \mathrm{C}\right)$ and RRS $\left(40.76 \pm 0.43^{\circ} \mathrm{C}\right)$-based powders. $\mathrm{T}_{\mathrm{g}}$ of spray dried powders is dependent on powder conformation and residual moisture content [90]. The mobility of the water molecules was limited in fiber-based formulation; that is why a noticeable decrease was observed in $\mathrm{Tg}$ values of these formulations comparing to the control [91]. The addition of resistant starches resulted in a prompt decrease of $T_{g}$ of the dried powders containing these starches as a chief component. The addition of MRS noticeably decreased of $\mathrm{Tg}$ from $38.77 \pm 1.10$ to $93.13 \pm 0.81^{\circ} \mathrm{C}$ as compared to other powders, 
while range acquired by addition of PRS from $40.76 \pm 0.43$ to $96.48 \pm 0.56{ }^{\circ} \mathrm{C}$, RRS and control $48.07 \pm 0.64$ to $97.89 \pm 0.48{ }^{\circ} \mathrm{C}, 50.08 \pm 0.98$ to $101.46 \pm 0.24{ }^{\circ} \mathrm{C}$, respectively.

The glycosidic residues are symmetrically present in pure maltodextrine, due to which its glass transition temperature is $106.4^{\circ} \mathrm{C}$. However, $\mathrm{Tg}$ is decreased when hexoses like D-mannose and D-glucose are added [92]. According to Lee and Moon, with the highest enthalpy of gelatinization $\mathrm{Tg}$ was recorded up to $89.1^{\circ} \mathrm{C}$ during the work on treated PRS [93]. These results are supported by the fact that a very little disruption of double helices occurs during the gelatinization of native granule. This suggests that lesser energy is required for disentangling and losing the interconnected double helices [94]. These double helices are formed by the outer branches of contiguous amylopectin chains [95]. However, some researchers investigated that, at different moisture contents (13.3-8.7\%), Tg of corn starches were recorded up to $59.22-67.34{ }^{\circ} \mathrm{C}$, respectively [96]. When the $\mathrm{Tg}$ is decreased the cell membrane is stabilized in liquid crystalline state after spray drying, and this decrease in Tg averts the consequential leakage of cell membrane during this process of phase transition. Free radical oxidation like chemical reactions are decelerated due to the glassy state of viscous carrier matrices. Hence, the glassy state of a matrix is considered significant for the prevention of further cell destruction and additional protection to cells during and after drying process $[16,46,48,92]$.

\subsection{Physicochemical Properties of Coating-Based Dried Powders}

After drying and storage, the residual moisture content $(\mathrm{MC})$, water activity $\left(\mathrm{a}_{\mathrm{w}}\right)$ and hygroscopicity $(\mathrm{H})$ values of the spray dried powders containing microencapsulated $L$. acidophillus KLDS 1.1003 were significant for MC, $\mathrm{a}_{\mathrm{w}}$ and $\mathrm{H}(p<0.01)$. These attributes were influenced by the composition of polysaccharide-based carrier matrices (Figure 3). The maize resistant starch (MRS)-based mixtures were categorized as containing the maximum $\mathrm{a}_{\mathrm{w}}$ and MC values, while, the control followed by RRS-based formulations had the lowest values of $a_{w}$ and MC (Figure 3A,B). The mean water activity of the powders ranging from $0.15 \pm 0.004$ to $0.30 \pm 0.008$ after 42 days storage is within the recommended limit of $(<0.6)$ to ensure the microbial stability $[25,97]$. According to Tonon et al. [98] $\mathrm{a}_{\mathrm{w}}$ lower than ( 0.30 positively affect the powder constancy due to decreasing biochemical reactions, resulting products with extended shelf life. Due to lower water activity, the availability of free water is decreased for biochemical reactions which increases the shelf life of probiotic powders [99], whereas similar findings were observed by Tonon et al. [100], although the range of differences were comparatively small: PRS showed the highest $\mathrm{a}_{\mathrm{w}}$ value (Figure 3A). Lowest water activity was observed $0.10 \pm 0.003$ at day 0 , while, with a considerable increase in $\mathrm{a}_{\mathrm{w}}(0.30 \pm 0.007)$ was recorded at day 42 of storage in control and MRS respectively (Figure 3B).

Control and RRS-based samples (1.45 $\pm 0.04-2.00 \pm 0.05 \%$ and $1.69 \pm 0.04-2.14 \pm 0.06 \%$ $w / w$ respectively) had lower residual water content values compared to MRS-based $2.64 \pm 0.07-3.36 \pm 0.09 w / w$ and PRS-based (Figure 3B) during 42 days of storage study at $25{ }^{\circ} \mathrm{C}$.

During storage period, the viability of probiotics is crucially effected by the moisture content in probiotic powders [63]. Muhammad et al. [16] found similar pattern for MC and $\mathrm{a}_{\mathrm{W}}$, during their study on polysaccharide-thermo protectant formulations for microencapsulation of Lactobacillus plantarum KLDS 1.0334 [84,89]. The storage studies conducted by Muzaffar and Kumar [101], Samborska et al. [102] and, Jaya and Das [103] also found the similar pattern for $\mathrm{a}_{\mathrm{w}}$ and MC of spray dried powders based on tamarind, honey, and mango powders. The composition of the carrier matrix, feeding rate, and inlet temperature conditions in the spray drying process chiefly govern the moisture content pattern in spray dried powders [104]. As far as the hygroscopic behavior is concerned, there is a higher moisture content in polysaccharide and protein-based spray dried products [105]. In our study the moisture contents of all formulations were observed comparing the suitable parameters of residual moisture for spray dried powders $(<5 \%)$, which represent a better shelf-life [106,107]. 
Likewise, water binding capacity and hygroscopicity (water absorption) of the constituents of the carrier medium matrix can affect $\mathrm{a}_{\mathrm{w}}$ and $\mathrm{MC}$ in food powders [95]. In line with our results, samples with the lowest moisture contents (control and RRS) had the lowest hygroscopicity values, and on the other hand, MRS has a high water absorption property (Figure $3 \mathrm{C}$ ) because the final $\mathrm{H}$ was significantly affected by the composition of feed solutions directly after drying. The increased water activity and moisture content could decrease hygroscopicity during storage, and thus can reduce the driving force for water absorption process $[16,106]$.

\subsection{Morphological Characteristics and Particle Size Distribution}

The span factors (Table 2) of RRS, PRS, and MRS-based microcapsules were $2.40 \pm 0.02$, $1.99 \pm 0.01$, and $3.44 \pm 0.05$, respectively as compared to control $2.43 \pm 0.00$. Microcapsules with lower span factors exhibit more homogeneity and a narrower range of particle size distribution.

Table 2 shows the volume mean diameters and span factors of microcapsules. The average volume mean diameters $(\mu \mathrm{m})$ of RRS, PRS, and MRS-based microcapsules were $41.55 \pm 0.15 \mu \mathrm{m}, 47.42 \pm 0.80 \mu \mathrm{m}$, and $52.28 \pm 1.08 \mu \mathrm{m}$, respectively, as compared to control $(27.00 \pm 0.04 \mu \mathrm{m})$. These results are comparable to the findings of Matos et al. [108] who stated that the diameters of stabilized starch particle in emulsions were in the range of 23-43 $\mu \mathrm{m}$. Besides to these results, Ashwar et al. [63] also investigated the microencapsulation of Lactobacilli by using RS4 rice starch and reported that the range of particle size diameter was $45.53 \pm 0.42$ to $47.12 \pm 0.98 \mu \mathrm{m}$. Similarly, Mirzaei et al. [64] reported the mean diameters of alginate-resistant starch beads produced by extrusion was in the range of 50-80 $\mu \mathrm{m}$. There are minute differences in particle sizes because of different materials and techniques were used for microencapsulation [109]. Nunes et al. [25] reported the sizes of different micro particles containing L. acidophilus La-5 varied from 6.68 to $19.30 \mu \mathrm{m}$ [37]. Additionally, Rajam and Anandharamakrishnan [59] studied Lactobacillus plantarum (MTCC 5422) containing capsules and verified that larger particle sizes $(6.68-23.89 \mu \mathrm{m})$ may be related to gelling and film forming properties of microencapsulating materials. Heidebach et al. [110] claimed that probiotics' microcapsules should be smaller than $100 \mu \mathrm{m}$ so to avoid a gritty sensation after consumption. The spray drying in general produces desirable particle sizes with smaller diameters to ensure the quality and homogeneity in functional food products [111]. Smaller (less than $100 \mu \mathrm{m}$ sized particles have a textural advantage due to which microencapsulated probiotics can be incorporated directly into a variety of food, pharmaceutical, and nutraceutical products [112].

Studies have shown that resistant starch-based micro particles have a persistent granular shape and they have larger sizes after spray-drying due to resilience against mechanical damage, higher crystallinity (35-38\%), and higher amylose contents than regular and waxy starches [95]. Hydration capacity of different polysaccharides also correlates the size differences. This might be due to the high hydrophilicity of polysaccharides (because of a larger number of amino acid and hydroxyl groups) and $\mathrm{COO}^{-}, \mathrm{SO}^{3}$ chemical groups which interact with water molecules via hydrogen bridges [48].

Moreover, there are several factors affecting the size of spray dried products. These factors include solubility, molecular weight, viscosity, and total solids of the medium solution, surface active components, nozzle diameter, type of atomizer, and the drying process [84]. According to Carneiro et al. [52] when highly viscous solutions are atomized they obstruct the emulsification rate and grainy particles are produced. The highly dispersed phase fraction can increase the consolidation of molecules by intensive colliding, which results in the production of molecules with larger diameters. The viscosity of the polymer solution is also affected by the molecular weight of the polymer which produces larger size droplets in spray drying. Thus, based on our findings it can be proposed that physical character and viscosity of the carrier solution can synergistically influence the mean size of the powdered particles of related hydrocolloids. 
Micrographs of the MRS, PRS, and RRS micro particles containing L. acidophilus KLDS 1.1003 were obtained by SEM are shown in Figure 4. The microstructural view, of all powders showed partly spherical particles with concavities resembling to other spraydried microcapsules [59]. Due to the fractional collapse and quick evaporation of moisture from the surface of the molecules after and during spray drying, characteristically rough, wrinkled, coarse, and crumpled surface micro capsules are produced [84,113]. Su et al. [114] and Fritzen-Freire et al. [50] also reported such concavities on products typically produced by spray drying. However, there were no fracture or visual cracks on their surfaces, which indicates minimal or no permeability to air and ensures greater shielding effect to probiotics against unfavorable conditions [59]. The micro particles produced with MRS (Figure 4D) presented a smooth surface with a regular shape. A round external surface was observed with similar characteristics by Domian et al. [115] after microencapsulating of oil with OSA-corn starch. Alike features were observed in the present work for micro particles containing MRS. RRS-based composites were slightly rough and shrunken (Figure 4B), because of a rapid loss of moisture from the porous surface of the matrix during spray drying $[97,116]$. The wrinkled and irregularly ellipsoidal shape of the PRS containing micro particles (Figure 4C) was due to their persistence against thermal denaturation [95,117].
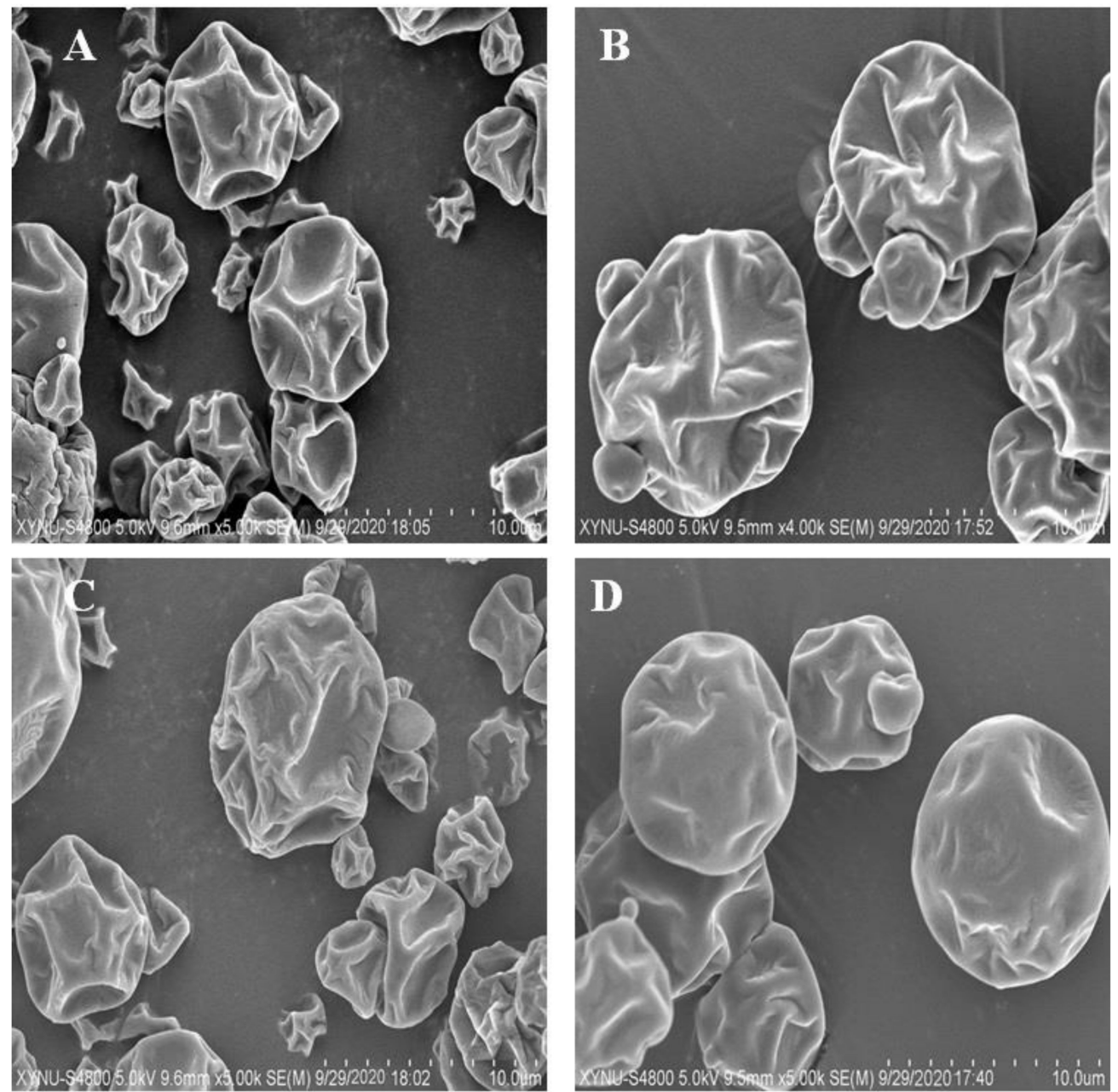

Figure 4. SEM micrographs of coated microcapsules containing L. acidophilus KLDS 1.1003; microcapsules showing spherical particles with concavities and surface dents in (A) Control, (B) Rice resistant starch, (C) Potato resistant starch, (D) Maize resistant starch. Bar size $=10 \mu \mathrm{m}$ equivalent in each image.

As seen in Figure 4, the microcapsules are not ruptured and have no surface crevices proving good structural integrity and suggesting very little penetrability of gas in the form 
of oxygen and water vapors [118]. Numerous constraints such as atomization process, composition, drying rates, and viscosity of the medium being spray dried, critically influence the morphological features of the spray dried products. Similarly, studies found that during the drying process, water and solutes movement is significantly restricted within viscous droplets due to which formation of bigger particles takes place without an obvious structural collapse [16]. Comparing to the control samples, polysaccharide containing samples showed a little collapse of microcapsules, and formation of a little wrinkled spherical particles took place (Figure 4). These wrinkled particles enhanced the contact surface area of micro composites with the microbial cells which increased their mutual adherence and produced well-structured and better microcapsules containing probiotics. Surprisingly, there were no noticeable structural distortions on the surface of the micro particles containing resistant starches [84].

\section{Conclusions}

Compared to non-encapsulated bacteria, overall a positive effect of all the starch-based compositions was observed regarding the improvement against thermal denaturation, improvement in tolerance against the simulated GI conditions for enzymatic hydrolysis, and cell viability at room temperature during storage. However, concerning the percentage of EE, thermal resistance, and gastrointestinal simulation, MRS-based microsphere encapsulating matrices has the higher protective capacity. Hence, MRS can be further investigated as a potential material to be incorporated as a new delivery carrier to administer the probiotics orally.

Author Contributions: Conceptualization, Z.M. and R.R.; methodology, Z.M.; software, Z.M. and R.R.; Z.M. validation, Z.M., R.Z. and M.Z.; formal analysis, Z.M. and R.R.; investigation, Z.M. and R.R.; resources, M.Z.; data curation, Z.M. and R.R.; writing-original draft preparation, Z.M. and R.R.; writing-review and editing, R.Z. and M.Z.; visualization, R.Z.; supervision, M.Z.; project administration, R.Z. and M.Z.; funding acquisition, M.Z. All authors have read and agreed to the published version of the manuscript.

Funding: This project was funded by the National Key Research Project of China (2017YFC1601002), the Program for Guangdong Introducing Innovative and Enterpreneurial Teams (2019BT02N112), Guangdong Academy of Agricultural Sciences Foundation of the Dean Project (BZ202003) and Agricultural Competitive Industry Discipline Team building Project of Guangdong Academy of Agricultural Sciences (202108TD).

Institutional Review Board Statement: Not applicable.

Informed Consent Statement: Not applicable.

Conflicts of Interest: The authors declare no conflict of interest.

\section{References}

1. Gur, J.; Mawuntu, M.; Martirosyan, D. FFC's Advancement of Functional Food Definition. Funct. Foods Health Dis. 2018, 8, 385. [CrossRef]

2. Granato, D.; Barba, F.J.; Bursać Kovačević, D.; Lorenzo, J.M.; Cruz, A.G.; Putnik, P. Functional Foods: Product Development, Technological Trends, Efficacy Testing, and Safety. Annu. Rev. Food Sci. Technol. 2020, 11, 93-118. [CrossRef] [PubMed]

3. FAO/WHO. Health and Nutrition Properties of Probiotics in Food including Powder Milk with Live Lactic Acid Bacteria Report. IEEE ISI 2013-2013 IEEE Int. Conf. Intell. Secur. Informatics Big Data, Emergent Threat. Decis. Secur. Informatics. 2006. Available online: http:/ / www.fao.org/2006 (accessed on 8 March 2021).

4. Ruiz Rodríguez, L.G.; Mohamed, F.; Bleckwedel, J.; Medina, R.; De Vuyst, L.; Hebert, E.M.; Mozzi, F. Diversity and functional properties of lactic acid bacteria isolated from wild fruits and flowers present in northern Argentina. Front. Microbiol. 2019, 10, 1091. [CrossRef] [PubMed]

5. Clemens, R.; Kadharmestan, C. Food. In An Overview of FDA Regulated Products: From Drugs and Cosmetics to Food and Tobacco; Academic Press: Cambridge, MA, USA, 2018; ISBN 9780128111550.

6. Pandey, K.R.; Naik, S.R.; Vakil, B.V. Probiotics, prebiotics and synbiotics-A review. J. Food Sci. Technol. 2015, $52,7577-7587$. [CrossRef]

7. Maldonado Galdeano, C.; Cazorla, S.I.; Lemme Dumit, J.M.; Vélez, E.; Perdigón, G. Beneficial effects of probiotic consumption on the immune system. Ann. Nutr. Metab. 2019, 74, 115-124. [CrossRef] 
8. Ibrahim, S.; El-Naggar, M.E.; Youssef, A.M.; Abdel-Aziz, M.S. Functionalization of Polystyrene Nanocomposite with Excellent Antimicrobial Efficiency for Food Packaging Application. J. Clust. Sci. 2020, 31, 1371-1382. [CrossRef]

9. Youssef, A.M.; El-Naggar, M.E.; Malhat, F.M.; El Sharkawi, H.M. Efficient removal of pesticides and heavy metals from wastewater and the antimicrobial activity of f-MWCNTs/PVA nanocomposite film. J. Clean. Prod. 2019, 206, 315-325. [CrossRef]

10. El-Naggar, M.E.; Soliman, R.A.; Morsy, O.M.; Abdel-Aziz, M.S. Nanoemulsion of Capsicum fruit extract as an eco-friendly antimicrobial agent for production of medical bandages. Biocatal. Agric. Biotechnol. 2020, 23, 101516. [CrossRef]

11. Infusino, F.; Marazzato, M.; Mancone, M.; Fedele, F.; Mastroianni, C.M.; Severino, P.; Ceccarelli, G.; Santinelli, L.; Cavarretta, E.; Marullo, A.G.M.; et al. Diet supplementation, probiotics, and nutraceuticals in SARS-CoV-2 infection: A scoping review. Nutrients 2020, 12, 1718. [CrossRef]

12. Mrityunjaya, M.; Pavithra, V.; Neelam, R.; Janhavi, P.; Halami, P.M.; Ravindra, P.V. Immune-Boosting, Antioxidant and Antiinflammatory Food Supplements Targeting Pathogenesis of COVID-19. Front. Immunol. 2020, 11, 570122. [CrossRef]

13. Dubey, M.R.; Patel, V.P. Probiotics: A Promising Tool for Calcium Absorption. Open Nutr. J. 2018, 12, 59-69. [CrossRef]

14. Marco, M.L.; Heeney, D.; Binda, S.; Cifelli, C.J.; Cotter, P.D.; Foligné, B.; Gänzle, M.; Kort, R.; Pasin, G.; Pihlanto, A.; et al. Health benefits of fermented foods: Microbiota and beyond. Curr. Opin. Biotechnol. 2017, 44, 94-102. [CrossRef] [PubMed]

15. Oh, B.; Kim, B.S.; Kim, J.W.; Kim, J.S.; Koh, S.J.; Kim, B.G.; Lee, K.L.; Chun, J. The Effect of Probiotics on Gut Microbiota during the Helicobacter pylori Eradication: Randomized Controlled Trial. Helicobacter 2016, 21, 165-174. [CrossRef]

16. Muhammad, Z.; Ramzan, R.; Huo, G.C.; Tian, H.; Bian, X. Integration of polysaccharide-thermoprotectant formulations for microencapsulation of Lactobacillus plantarum, appraisal of survivability and physico-biochemical properties during storage of spray dried powders. Food Hydrocoll. 2017, 66, 286-295. [CrossRef]

17. Youssef, H.F.; El-Naggar, M.E.; Fouda, F.K.; Youssef, A.M. Antimicrobial packaging film based on biodegradable CMC/PVAzeolite doped with noble metal cations. Food Packag. Shelf Life 2019, 22, 100378. [CrossRef]

18. Saez-Lara, M.J.; Gomez-Llorente, C.; Plaza-Diaz, J.; Gil, A. The role of probiotic lactic acid bacteria and bifidobacteria in the prevention and treatment of inflammatory bowel disease and other related diseases: A systematic review of randomized human clinical trials. BioMed Res. Int. 2015, 2015, 505878. [CrossRef]

19. Succi, M.; Tremonte, P.; Pannella, G.; Tipaldi, L.; Cozzolino, A.; Coppola, R.; Sorrentino, E. Survival of commercial probiotic strains in dark chocolate with high cocoa and phenols content during the storage and in a static in vitro digestion model. J. Funct. Foods 2017, 35, 60-67. [CrossRef]

20. FDA Federal Register. Substances Generally Recognized as Safe. Available online: https://www.federalregister.gov/foodsubstances-generally-recognized-as-safe (accessed on 8 March 2021).

21. Feng, K.; Zhai, M.Y.; Zhang, Y.; Linhardt, R.J.; Zong, M.H.; Li, L.; Wu, H. Improved Viability and Thermal Stability of the Probiotics Encapsulated in a Novel Electrospun Fiber Mat. J. Agric. Food Chem. 2018, 66, 10890-10897. [CrossRef]

22. Min, M.; Bunt, C.R.; Mason, S.L.; Hussain, M.A. Non-dairy probiotic food products: An emerging group of functional foods. Crit. Rev. Food Sci. Nutr. 2019, 59, 2626-2641. [CrossRef]

23. Ross, R.P.; Desmond, C.; Fitzgerald, G.F.; Stanton, C. Overcoming the technological hurdles in the development of probiotic foods. Proc. J. Appl. Microbiol. 2005, 98, 1410-1417. [CrossRef]

24. Doleyres, Y.; Lacroix, C. Technologies with free and immobilised cells for probiotic bifidobacteria production and protection. Int. Dairy J. 2005, 15, 973-988. [CrossRef]

25. Nunes, G.L.; de Etchepare, M.A.; Cichoski, A.J.; Zepka, L.Q.; Jacob Lopes, E.; Barin, J.S.; de Flores, É.M.M.; da de Silva, C.B.; de Menezes, C.R. Inulin, hi-maize, and trehalose as thermal protectants for increasing viability of Lactobacillus acidophilus encapsulated by spray drying. LWT Food Sci. Technol. 2018, 89, 128-133. [CrossRef]

26. de Etchepare, M.A.; Raddatz, G.C.; Cichoski, A.J.; Flores, É.M.M.; Barin, J.S.; Queiroz Zepka, L.; Jacob-Lopes, E.; Grosso, C.R.F.; de Menezes, C.R. Effect of resistant starch (Hi-maize) on the survival of Lactobacillus acidophilus microencapsulated with sodium alginate. J. Funct. Foods 2016, 21, 321-329. [CrossRef]

27. Di Pretoro, A.; Manenti, F. Spray Drying. In Tunable Low-Power Low-Noise Amplifier for Healthcare Applications; Springer: Berlin/Heidelberg, Germany, 2020; pp. 65-74.

28. Arslan-Tontul, S.; Erbas, M. Single and double layered microencapsulation of probiotics by spray drying and spray chilling. LWT 2017, 81, 160-169. [CrossRef]

29. Zanjani, M.A.K.; Ehsani, M.R.; Ghiassi Tarzi, B.; Sharifan, A. Promoting Lactobacillus casei and Bifidobacterium adolescentis survival by microencapsulation with different starches and chitosan and poly L-lysine coatings in ice cream. J. Food Process. Preserv. 2018, 42, e13318. [CrossRef]

30. Márquez-Gómez, M.; Galicia-García, T.; Márquez-Meléndez, R.; Ruiz-Gutiérrez, M.; Quintero-Ramos, A. Spray-dried microencapsulation of orange essential oil using modified rice starch as wall material. J. Food Process. Preserv. 2018, 42, e13428. [CrossRef]

31. Shafiei, Y. Probiotic and Synbiotic Yogurt Production Using Free or Alginate/Resistant Starch Microencapsulated Lactobacillus plantarum. In Role of Materials Science in Food Bioengineering; Elsevier: Amsterdam, The Netherlands, 2018; pp. 301-328.

32. Zaman, S.A.; Sarbini, S.R. The potential of resistant starch as a prebiotic. Crit. Rev. Biotechnol. 2016, 36, 1-7. [CrossRef] [PubMed]

33. Liu, H.; Xie, M.; Nie, S. Recent trends and applications of polysaccharides for microencapsulation of probiotics. Food Front. 2020, 1, 45-59. [CrossRef]

34. Ashwar, B.A.; Gani, A.; Gani, A.; Shah, A.; Masoodi, F.A. Production of RS4 from rice starch and its utilization as an encapsulating agent for targeted delivery of probiotics. Food Chem. 2018, 239, 287-294. [CrossRef] 
35. Liu, Y.; Liu, J.; Kong, J.; Wang, R.; Liu, M.; Strappe, P.; Blanchard, C.; Zhou, Z. Citrate esterification of debranched waxy maize starch: Structural, physicochemical and amylolysis properties. Food Hydrocoll. 2020, 104, 105704. [CrossRef]

36. Khosravi Zanjani, M.A.; Ehsani, M.R.; Tarzi, B.G.; Sharifan, A. Promoting probiotics survival by microencapsualtion with hylon starch and genipin cross-linked coatings in simulated gastro-intestinal condition and heat treatment. Iran. J. Pharm. Res. 2018, 17, 753-766. [CrossRef] [PubMed]

37. de Araújo Etchepare, M.; Nunes, G.L.; Nicoloso, B.R.; Barin, J.S.; Moraes Flores, E.M.; de Oliveira Mello, R.; Ragagnin de Menezes, C. Improvement of the viability of encapsulated probiotics using whey proteins. LWT 2020, 117, 108601. [CrossRef]

38. Yasmin, I.; Saeed, M.; Pasha, I.; Zia, M.A. Development of Whey Protein Concentrate-Pectin-Alginate Based Delivery System to Improve Survival of B. longum BL-05 in Simulated Gastrointestinal Conditions. Probiotics Antimicrob. Proteins 2019, 11, 413-426. [CrossRef]

39. Iqbal, R.; Zahoor, T.; Huma, N.; Jamil, A.; Ünlü, G. In-vitro GIT Tolerance of Microencapsulated Bifidobacterium bifidum ATCC 35914 Using Polysaccharide-Protein Matrix. Probiotics Antimicrob. Proteins 2019, 11, 830-839. [CrossRef]

40. Boeve, J.; Joye, I.J. Food-grade strategies to increase stability of whey protein particles: Particle hardening through aldehyde treatment. Food Hydrocoll. 2020, 100, 105353. [CrossRef]

41. Arroyo-Maya, I.J.; McClements, D.J. Biopolymer nanoparticles as potential delivery systems for anthocyanins: Fabrication and properties. Food Res. Int. 2015, 69, 1-8. [CrossRef]

42. Wagoner, T.B.; Foegeding, E.A. Whey protein-pectin soluble complexes for beverage applications. Food Hydrocoll. 2017, 63, 130-138. [CrossRef]

43. Khatkar, A.B.; Kaur, A.; Khatkar, S.K.; Mehta, N. Characterization of heat-stable whey protein: Impact of ultrasound on rheological, thermal, structural and morphological properties. Ultrason. Sonochem. 2018, 49, 333-342. [CrossRef] [PubMed]

44. Fu, N.; Chen, X.D. Towards a maximal cell survival in convective thermal drying processes. Food Res. Int. 2011, 44, 1127-1149. [CrossRef]

45. Ning, N.; Fu, S.; Zhang, W.; Chen, F.; Wang, K.; Deng, H.; Zhang, Q.; Fu, Q. Realizing the enhancement of interfacial interaction in semicrystalline polymer/filler composites via interfacial crystallization. Prog. Polym. Sci. 2012, 37, 1425-1455. [CrossRef]

46. Lapsiri, W.; Bhandari, B.; Wanchaitanawong, P. Stability and Probiotic Properties of Lactobacillus plantarum Spray-Dried with Protein and Other Protectants. Dry. Technol. 2013, 31, 1723-1733. [CrossRef]

47. Ayama, H.; Sumpavapol, P.; Chanthachum, S. Effect of encapsulation of selected probiotic cell on survival in simulated gastrointestinal tract condition. Songklanakarin J. Sci. Technol. 2014, 36, 291-299.

48. de Araújo Etchepare, M.; Raddatz, G.C.; de Moraes Flores, É.M.; Zepka, L.Q.; Jacob-Lopes, E.; Barin, J.S.; Ferreira Grosso, C.R.; de Menezes, C.R. Effect of resistant starch and chitosan on survival of Lactobacillus acidophilus microencapsulated with sodium alginate. LWT Food Sci. Technol. 2016, 65, 511-517. [CrossRef]

49. Association of Official Analytical Chemists. Official Methods of Analysis; AOAC: Rockville, MD, USA, 2012.

50. Fritzen-Freire, C.B.; Prudêncio, E.S.; Amboni, R.D.M.C.; Pinto, S.S.; Negrão-Murakami, A.N.; Murakami, F.S. Microencapsulation of bifidobacteria by spray drying in the presence of prebiotics. Food Res. Int. 2012, 45, 306-312. [CrossRef]

51. Lv, Y.; Zhang, L.; Li, M.; He, X.; Hao, L.; Dai, Y. Physicochemical properties and digestibility of potato starch treated by ball milling with tea polyphenols. Int. J. Biol. Macromol. 2019, 129, 207-213. [CrossRef] [PubMed]

52. Carneiro, H.C.F.; Tonon, R.V.; Grosso, C.R.F.; Hubinger, M.D. Encapsulation efficiency and oxidative stability of flaxseed oil microencapsulated by spray drying using different combinations of wall materials. J. Food Eng. 2013, 115, 443-451. [CrossRef]

53. Akhavan Mahdavi, S.; Jafari, S.M.; Assadpoor, E.; Dehnad, D. Microencapsulation optimization of natural anthocyanins with maltodextrin, gum Arabic and gelatin. Int. J. Biol. Macromol. 2016, 85, 379-385. [CrossRef]

54. Dabija, A.; Nechifor, I. Study regarding the microencapsulation of food ingredients in alginates. Ann. Food Sci. Technol. 2015, $16,20-26$.

55. Muhammad, Z.; Ramzan, R.; Abdelazez, A.; Amjad, A.; Afzaal, M.; Zhang, S.; Pan, S. Assessment of the antimicrobial potentiality and functionality of Lactobacillus plantarum strains isolated from the conventional inner mongolian fermented cheese against foodborne pathogens. Pathogens 2019, 8, 71. [CrossRef]

56. Ying, D.Y.; Schwander, S.; Weerakkody, R.; Sanguansri, L.; Gantenbein-Demarchi, C.; Augustin, M.A. Microencapsulated Lactobacillus rhamnosus GG in whey protein and resistant starch matrices: Probiotic survival in fruit juice. J. Funct. Foods 2013, 5, 98-105. [CrossRef]

57. Domian, E.; Brynda-Kopytowska, A.; Cenkier, J.; Świrydow, E. Selected properties of microencapsulated oil powders with commercial preparations of maize OSA starch and trehalose. J. Food Eng. 2015, 152, 72-84. [CrossRef]

58. Ray, S.; Raychaudhuri, U.; Chakraborty, R. An overview of encapsulation of active compounds used in food products by drying technology. Food Biosci. 2016, 13, 76-83. [CrossRef]

59. Rajam, R.; Anandharamakrishnan, C. Spray freeze drying method for microencapsulation of Lactobacillus plantarum. J. Food Eng. 2015, 166, 95-103. [CrossRef]

60. Bustamante, M.; Oomah, B.D.; Rubilar, M.; Shene, C. Effective Lactobacillus plantarum and Bifidobacterium infantis encapsulation with chia seed (Salvia hispanica L.) and flaxseed (Linum usitatissimum L.) mucilage and soluble protein by spray drying. Food Chem. 2017, 216, 97-105. [CrossRef] [PubMed]

61. Arslan, S.; Erbas, M.; Tontul, I.; Topuz, A. Microencapsulation of probiotic Saccharomyces cerevisiae var: Boulardii with different wall materials by spray drying. LWT 2015, 63, 685-690. [CrossRef] 
62. Huang, S.; Vignolles, M.L.; Chen, X.D.; Le Loir, Y.; Jan, G.; Schuck, P.; Jeantet, R. Spray drying of probiotics and other food-grade bacteria: A review. Trends Food Sci. Technol. 2017, 63, 1-17. [CrossRef]

63. Ashwar, B.A.; Gani, A.; Shah, A.; Masoodi, F.A. Production of RS4 from rice by acetylation: Physico-chemical, thermal, and structural characterization. Starch-Stärke 2017, 69, 1600052. [CrossRef]

64. Mirzaei, H.; Pourjafar, H.; Homayouni, A. Effect of calcium alginate and resistant starch microencapsulation on the survival rate of Lactobacillus acidophilus La5 and sensory properties in Iranian white brined cheese. Food Chem. 2012, 132, 1966-1970. [CrossRef]

65. Sultana, K.; Godward, G.; Reynolds, N.; Arumugaswamy, R.; Peiris, P.; Kailasapathy, K. Encapsulation of probiotic bacteria with alginate-starch and evaluation of survival in simulated gastrointestinal conditions and in yoghurt. Int. J. Food Microbiol. 2000, 62, 47-55. [CrossRef]

66. Pitigraisorn, P.; Srichaisupakit, K.; Wongpadungkiat, N.; Wongsasulak, S. Encapsulation of Lactobacillus acidophilus in moistheat-resistant multilayered microcapsules. J. Food Eng. 2017, 192, 11-18. [CrossRef]

67. Corona-Hernandez, R.I.; Álvarez-Parrilla, E.; Lizardi-Mendoza, J.; Islas-Rubio, A.R.; de la Rosa, L.A.; Wall-Medrano, A. Structural stability and viability of microencapsulated probiotic bacteria: A review. Compr. Rev. Food Sci. Food Saf. 2013, 12, 614-628. [CrossRef]

68. de Vos, P.; Faas, M.M.; Spasojevic, M.; Sikkema, J. Encapsulation for preservation of functionality and targeted delivery of bioactive food components. Int. Dairy J. 2010, 20, 292-302. [CrossRef]

69. Liu, Y.; Sun, Y.; Sun, L.; Rizwan-ur-Rehman; Wang, Y. In vitro and in vivo study of sodium polyacrylate grafted alginate as microcapsule matrix for live probiotic delivery. J. Funct. Foods 2016, 24, 429-437. [CrossRef]

70. López-Rubio, A.; Lagaron, J.M. Whey protein capsules obtained through electrospraying for the encapsulation of bioactives. Innov. Food Sci. Emerg. Technol. 2012, 13, 200-206. [CrossRef]

71. Sabikhi, L.; Babu, R.; Thompkinson, D.K.; Kapila, S. Resistance of microencapsulated Lactobacillus acidophilus LA1 to processing treatments and simulated gut conditions. Food Bioprocess Technol. 2010, 3, 586-593. [CrossRef]

72. Gebara, C.; Chaves, K.S.; Ribeiro, M.C.E.; Souza, F.N.; Grosso, C.R.F.; Gigante, M.L. Viability of Lactobacillus acidophilus La5 in pectin-whey protein microparticles during exposure to simulated gastrointestinal conditions. Food Res. Int. 2013, 51, 872-878 [CrossRef]

73. Pankasemsuk, T.; Apichartsrangkoon, A.; Worametrachanon, S.; Techarang, J. Encapsulation of Lactobacillus casei 01 by alginate along with hi-maize starch for exposure to a simulated gut model. Food Biosci. 2016, 16, 32-36. [CrossRef]

74. Krasaekoopt, W.; Watcharapoka, S. Effect of addition of inulin and galactooligosaccharide on the survival of microencapsulated probiotics in alginate beads coated with chitosan in simulated digestive system, yogurt and fruit juice. LWT Food Sci. Technol. 2014, 57, 761-766. [CrossRef]

75. Chotiko, A.; Sathivel, S. Development of a combined low-methoxyl-pectin and rice-bran-extract delivery system to improve the viability of Lactobacillus plantarum under acid and bile conditions. LWT Food Sci. Technol. 2016, 66, 420-427. [CrossRef]

76. Abbas, H.M.K.; Huang, H.X.; Yang, Y.F.; Xie, Y.H.; Zou, J.F.; Xue, S.D.; Song, D.G.; Wu, T.Q.; Li, J.X.; Zhong, Y.J. Characterization of Starch in Cucurbita moschata Germplasms throughout Fruit Development. J. Agric. Food Chem. 2020, 68, 68. [CrossRef]

77. Zhang, Y.; Lin, J.; Zhong, Q. The increased viability of probiotic Lactobacillus salivarius NRRL B-30514 encapsulated in emulsions with multiple lipid-protein-pectin layers. Food Res. Int. 2015, 71, 9-15. [CrossRef]

78. Hoobin, P.; Burgar, I.; Zhu, S.; Ying, D.; Sanguansri, L.; Augustin, M.A. Water sorption properties, molecular mobility and probiotic survival in freeze dried protein-carbohydrate matrices. Food Funct. 2013, 4, 1376-1386. [CrossRef] [PubMed]

79. Anal, A.K.; Singh, H. Recent advances in microencapsulation of probiotics for industrial applications and targeted delivery. Trends Food Sci. Technol. 2007, 18, 240-251. [CrossRef]

80. Ying, D.Y.; Sanguansri, L.; Weerakkody, R.; Bull, M.; Singh, T.K.; Augustin, M.A. Effect of encapsulant matrix on stability of microencapsulated probiotics. J. Funct. Foods 2016, 25, 447-458. [CrossRef]

81. Gul, L.B.; Gul, O.; Yilmaz, M.T.; Dertli, E.; Con, A.H. Optimization of cryoprotectant formulation to enhance the viability of Lactobacillus brevis ED25: Determination of storage stability and acidification kinetics in sourdough. J. Food Process. Preserv. 2020, 44, 44. [CrossRef]

82. Chen, Y.; Krings, S.; Booth, J.R.; Bon, S.A.F.; Hingley-Wilson, S.; Keddie, J.L. Introducing Porosity in Colloidal Biocoatings to Increase Bacterial Viability. Biomacromolecules 2020, 21, 4545-4558. [CrossRef]

83. Kalita, D.; Saikia, S.; Gautam, G.; Mukhopadhyay, R. LWT-Food Science and Technology Characteristics of synbiotic spray dried powder of litchi juice with Lactobacillus plantarum and different carrier materials. LWT Food Sci. Technol. 2018, 87, 351-360. [CrossRef]

84. Pavli, F.; Tassou, C.; Nychas, G.J.E.; Chorianopoulos, N. Probiotic incorporation in edible films and coatings: Bioactive solution for functional foods. Int. J. Mol. Sci. 2018, 19, 150. [CrossRef]

85. Hached, F.; Vinatier, C.; Pinta, P.G.; Hulin, P.; Le Visage, C.; Weiss, P.; Guicheux, J.; Billon-Chabaud, A.; Grimandi, G. Polysaccharide hydrogels support the long-Term viability of encapsulated human mesenchymal stem cells and their ability to secrete immunomodulatory factors. Stem Cells Int. 2017, 2017, 9303598. [CrossRef]

86. Huang, R.; Tao, X.; Wan, C.; Li, S.; Xu, H.; Xu, F.; Shah, N.P.; Wei, H. In vitro probiotic characteristics of Lactobacillus plantarum ZDY 2013 and its modulatory effect on gut microbiota of mice. J. Dairy Sci. 2015, 98, 5850-5861. [CrossRef] 
87. Hugo, A.A.; Bruno, F.; Golowczyc, M.A. Whey permeate containing galacto-oligosaccharides as a medium for biomass production and spray drying of Lactobacillus plantarum CIDCA 83114. LWT Food Sci. Technol. 2016, 69, 185-190. [CrossRef]

88. Yao, M.; Xie, J.; Du, H.; McClements, D.J.; Xiao, H.; Li, L. Progress in microencapsulation of probiotics: A review. Compr. Rev. Food Sci. Food Saf. 2020, 19, 857-874. [CrossRef] [PubMed]

89. Yonekura, L.; Sun, H.; Soukoulis, C.; Fisk, I. Microencapsulation of Lactobacillus acidophilus NCIMB 701748 in matrices containing soluble fibre by spray drying: Technological characterization, storage stability and survival after in vitro digestion. J. Funct. Foods 2014, 6, 205-214. [CrossRef]

90. Wang, Y.; Lu, Z.; Lv, F.; Bie, X. Study on microencapsulation of curcumin pigments by spray drying. Eur. Food Res. Technol. 2009, 229, 391-396. [CrossRef]

91. Mainville, I.; Arcand, Y.; Farnworth, E.R. A dynamic model that simulates the human upper gastrointestinal tract for the study of probiotics. Int. J. Food Microbiol. 2005, 99, 287-296. [CrossRef]

92. Soukoulis, C.; Behboudi-Jobbehdar, S.; Yonekura, L.; Parmenter, C.; Fisk, I. Impact of Milk Protein Type on the Viability and Storage Stability of Microencapsulated Lactobacillus acidophilus NCIMB 701748 Using Spray Drying. Food Bioprocess Technol. 2014, 7, 1255-1268. [CrossRef]

93. Lee, C.J.; Moon, T.W. Structural characteristics of slowly digestible starch and resistant starch isolated from heat-moisture treated waxy potato starch. Carbohydr. Polym. 2015, 125, 200-205. [CrossRef]

94. Kim, H.R.; Choi, S.J.; Choi, H.D.; Park, C.S.; Moon, T.W. Amylosucrase-modified waxy potato starches recrystallized with amylose: The role of amylopectin chain length in formation of low-digestible fractions. Food Chem. 2020, 318, 126490. [CrossRef]

95. $\mathrm{Xu}, \mathrm{Y}$. Resistant starch content, molecular structure and physicochemical properties of starches in Virginia-grown corn, potato and mungbean. J. Cereal. Oilseeds 2013, 4, 10-18. [CrossRef]

96. Li, S.; Wang, C.; Fu, X.; Li, C.; He, X.; Zhang, B.; Huang, Q. Encapsulation of lutein into swelled cornstarch granules: Structure, stability and in vitro digestion. Food Chem. 2018, 268, 362-368. [CrossRef]

97. Ashwar, B.A.; Gani, A.; Gani, A.; Ahmad, M.; Shah, A. Encapsulating probiotics in novel resistant starch wall material for production of rice flour extrudates. LWT 2021, 140, 110839. [CrossRef]

98. Tonon, R.V.; Baroni, A.F.; Brabet, C.; Gibert, O.; Pallet, D.; Hubinger, M.D. Water sorption and glass transition temperature of spray dried açai (Euterpe oleracea Mart.) juice. J. Food Eng. 2009, 94, 215-221. [CrossRef]

99. Tonon, R.V.; Freitas, S.S.; Hubinger, M.D. Spray drying of açai (Euterpe oleraceae Mart.) juice: Effect of inlet air temperature and type of carrier agent. J. Food Process. Preserv. 2011, 35, 691-700. [CrossRef]

100. Tonon, R.V.; Brabet, C.; Hubinger, M.D. Spray Drying of Acai (Euterpe Oleracea Mart) Juice: Effect of Process Variables and Type of Carrier Agent on Products Quality and Stability; Nova Science Publishers: Hauppauge, NY, USA, 2011; ISBN 9781611224214.

101. Muzaffar, K.; Kumar, P. Moisture sorption isotherms and storage study of spray dried tamarind pulp powder. Powder Technol. 2016, 291, 322-327. [CrossRef]

102. Samborska, K. Powdered honey-drying methods and parameters, types of carriers and drying aids, physicochemical properties and storage stability. Trends Food Sci. Technol. 2019, 88, 133-142. [CrossRef]

103. Samborska, K.; Langa, E.; Bakier, S. Changes in the physical properties of honey powder during storage. Int. J. Food Sci. Technol. 2015, 50, 1359-1365. [CrossRef]

104. Barbosa-Canovas, G.V.; Ortega-Rivas, E.; Juliano, P.; Yan, H. Food Powders: Physical Properties, Processing, and Functionality; Washington State University: Washington, DC, USA, 2005; ISBN 0-306-47806-4.

105. Neves, M.I.L.; Desobry-Banon, S.; Perrone, I.T.; Desobry, S.; Petit, J. Encapsulation of curcumin in milk powders by spray-drying: Physicochemistry, rehydration properties, and stability during storage. Powder Technol. 2019, 345, 601-607. [CrossRef]

106. Ananta, E.; Volkert, M.; Knorr, D. Cellular injuries and storage stability of spray-dried Lactobacillus rhamnosus GG. Int. Dairy J. 2005, 15, 399-409. [CrossRef]

107. Abbas, H.M.K.; Huang, H.X.; Huang, W.J.; Xue, S.D.; Yan, S.J.; Wu, T.Q.; Li, J.X.; Zhong, Y.J. Evaluation of Metabolites and Antioxidant Activity in Pumpkin Species. Nat. Prod. Commun. 2020, 15, 15. [CrossRef]

108. Matos, M.; Timgren, A.; Sjöö, M.; Dejmek, P.; Rayner, M. Preparation and encapsulation properties of double Pickering emulsions stabilized by quinoa starch granules. Colloids Surf. A Physicochem. Eng. Asp. 2013, 423, 147-153. [CrossRef]

109. Roshanzamir, M.; Jafari, M.; Molaee, A.E.; Ghasemkhani, I.; Hanifpor, M. The Survival of Probiotic Bacteria and Sensory Properties of Yogurt Affected by Microencapsulation with Resistant Starch. J. Food Saf. Hyg. 2017, 3, 59-64.

110. Heidebach, T.; Först, P.; Kulozik, U. Microencapsulation of Probiotic Cells for Food Applications. Crit. Rev. Food Sci. Nutr. 2012, 52, 291-311. [CrossRef]

111. Iravani, S.; Korbekandi, H.; Mirmohammadi, S.V. Technology and potential applications of probiotic encapsulation in fermented milk products. J. Food Sci. Technol. 2015, 52, 4679-4696. [CrossRef] [PubMed]

112. Borrás-Enríquez, A.J.; de la Cruz-Martínez, A.; Delgado-Portales, R.E.; González-Chávez, M.M.; Abud-Archila, M.; Moscosa-Santillán, M. Microbiological-physicochemical assessment and gastrointestinal simulation of functional (Probiotic and symbiotic) gouda-type cheeses during ripening. Rev. Mex. Ing. Quim. 2018, 17, 791-803. [CrossRef]

113. Khem, S.; Bansal, V.; Small, D.M.; May, B.K. Comparative influence of $\mathrm{pH}$ and heat on whey protein isolate in protecting Lactobacillus plantarum A17 during spray drying. Food Hydrocoll. 2016, 54, 162-169. [CrossRef]

114. Su, Y.; Zheng, X.; Zhao, Q.; Fu, N.; Xiong, H.; Wu, W.D.; Chen, X.D. Spray drying of Lactobacillus rhamnosus GG with calcium-containing protectant for enhanced viability. Powder Technol. 2019, 358, 87-94. [CrossRef] 
115. Domian, E.; Brynda-Kopytowska, A.; Oleksza, K. Rheological properties and physical stability of o/w emulsions stabilized by OSA starch with trehalose. Food Hydrocoll. 2015, 44, 49-58. [CrossRef]

116. Mokarram, R.R.; Mortazavi, S.A.; Najafi, M.B.H.; Shahidi, F. The influence of multi stage alginate coating on survivability of potential probiotic bacteria in simulated gastric and intestinal juice. Food Res. Int. 2009, 42, 1040-1045. [CrossRef]

117. Abbas, H.M.K.; Huang, H.X.; Wang, A.J.; Wu, T.Q.; Xue, S.D.; Ahmad, A.; Xie, D.S.; Li, J.X.; Zhong, Y.J. Metabolic and transcriptomic analysis of two Cucurbita moschata germplasms throughout fruit development. BMC Genom. 2020, $21,1-13$. [CrossRef] [PubMed]

118. Khorasani, A.C.; Shojaosadati, S.A. Bacterial nanocellulose-pectin bionanocomposites as prebiotics against drying and gastrointestinal condition. Int. J. Biol. Macromol. 2016, 83, 9-18. [CrossRef] 